Document downloaded from:

http://hdl.handle.net/10251/124682

This paper must be cited as:

Tomas-Vidal, A.; Monge-Ortiz, R.; Jover Cerda, M.; Martínez-Llorens, S. (2019). Apparent digestibility and protein quality evaluation of selected feed ingredients in Seriola dumerili. Journal of the World Aquaculture Society. https://doi.org/10.1111/jwas.12597

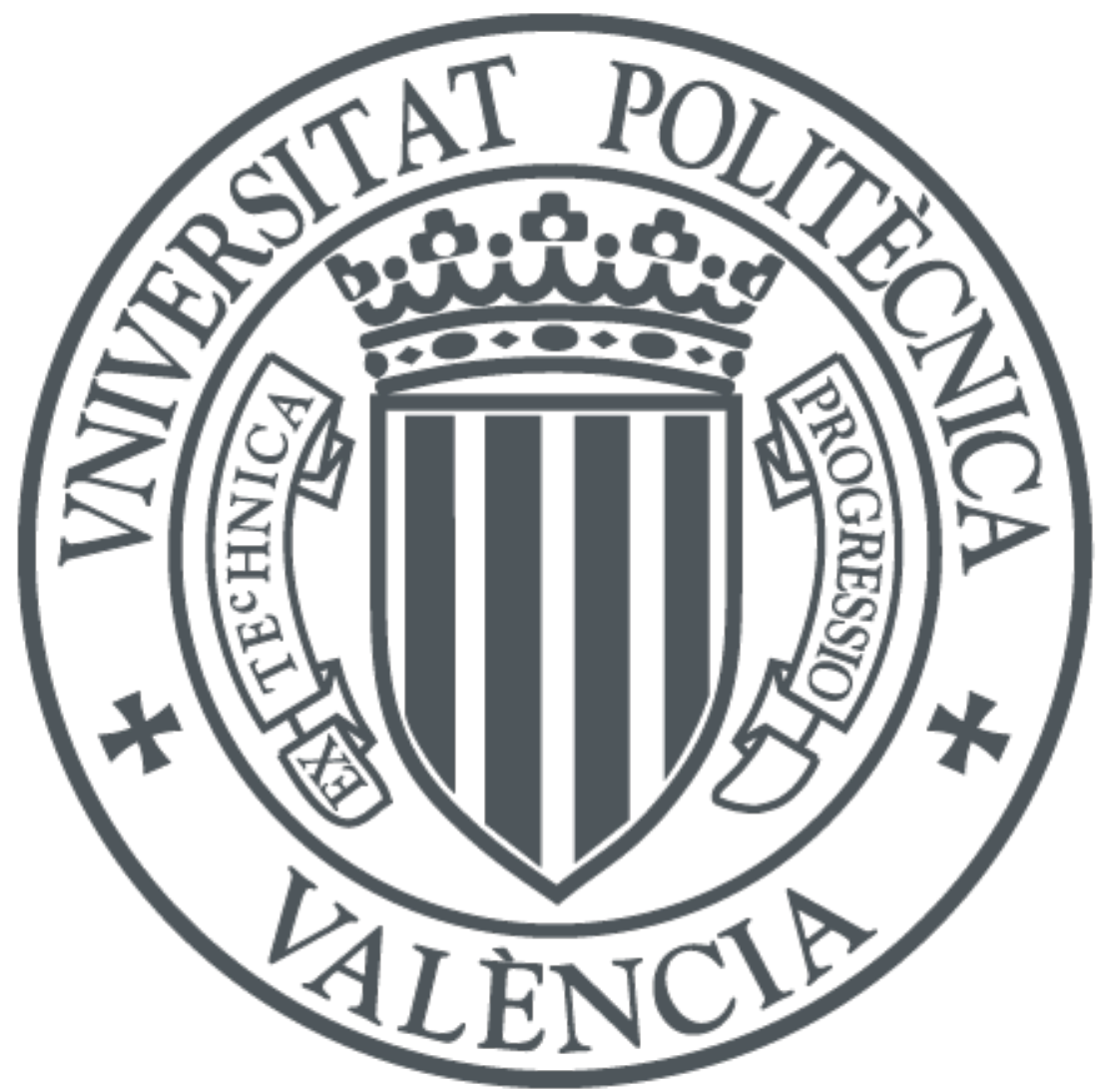

The final publication is available at

http://doi.org/10.1111/jwas.12597

Copyright Blackwell Publishing

Additional Information 


\section{World Aquaculture Society}

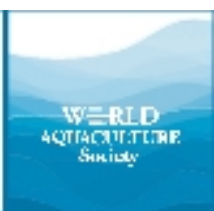

\section{Apparent Digestibility and Protein Quality Evaluation of Selected Feed Ingredients in Seriola dumerili.}

\begin{tabular}{|r|l|}
\hline Journal: & Journal of the World Aquaculture Society \\
\hline Manuscript ID & JWAS-17-025.R4 \\
\hline Manuscript Type: & Fundamental Studies \\
\hline Author: & O8-Nov-2018 \\
\hline Complete List of Authors: & $\begin{array}{l}\text { Tomas Vidal, Ana; Universidad Politecnica de Valencia, Inctituto de } \\
\text { Ciencia y Tecnología Animal } \\
\text { Monge-Ortiz, Raquel; Universitat Politècnica València, Institute of Animal } \\
\text { Science and Technology } \\
\text { JOVER, MIGUEL; UNIVERSIDAD POLITECNICA VALENCIA, CIENCIA } \\
\text { ANIMAL } \\
\text { Martínez-Llorens, Silvia; Polytechnic University of Valencia, Animal } \\
\text { Science }\end{array}$ \\
\hline Keywords: & $\begin{array}{l}\text { yellowtail, protein quality, amino acids, protein and lipid digestibility, } \\
\text { Chemical Score }\end{array}$ \\
\hline
\end{tabular}

\section{SCHOLARONE \\ Manuscripts}




\title{
EDITORIAL CERTIFICATE
}

\author{
This document certifies that the article listed below was edited and revised for \\ proper English language, syntax, spelling, punctuation and style by Vanesa \\ Vega Dorado (B.A. English Philology and M.A. Applied Linguistics).
}

\author{
ARTICLE TITLE \\ Apparent digestibility and protein quality evaluation of selected feed \\ ingredients in Seriola dumerili
}

\begin{abstract}
AUTHORS
Silvia Martínez-Llorens, Ana Tomás-Vidal, Raquel Monge, Miguel Jover-Cerdá
\end{abstract}

DATE ISSUED

October $10^{\text {th }} 2016$

\begin{abstract}
Neither the research content nor the author's intention were in any way altered during the editing process. Documents receiving this certification should be English ready for publication. However, the author has the ability to accept or reject the suggestions and changes made to the manuscript.
\end{abstract}



Ingredients in Seriola dumerili.

10 Ana Tomás-Vidal, Raquel Monge-Ortiz, Miguel Jover-Cerdá, Silvia Martínez-Llorens.

11 Research Group of Aquaculture and Biodiversity. Institute of Animal Science and

12 Technology. Universitat Politècnica de València. Camino de Vera, 14. 46071-Valencia, 13 Spain.

19 Corresponding author: Raquel Monge-Ortiz, Universitat Politècnica València.

20 Camino de Vera, 14. 46071-Valencia (Spain). Tel.: 34-96-3879752; Fax: 34-96-

213877439. E-mail: silmarll@dca.upv.es. 
Abstract

The apparent digestibility coefficients (ADC) of dry matter, crude protein,

crude lipid, and amino acids in fish, krill, squid, meat, defatted krill, soybean,

wheat gluten, wheat, camilina, pea, sunflower and fava bean meals were

determined for juvenile Seriola dumerili. The results showed that the ADC of dry matter for yellowtail ranged from 57.7 to $87.2 \%$ for animal ingredients, and from 42.2 to 82.2\% for plant ingredients. ADC of protein exceeding 90\% were observed in fishmeal, while camilina meal and fava bean meal presented the lowest values. Pea meal presented the lowest lipid ADC (83.5\%). The availabilities were generally higher in animal ingredients than those in vegetal ones. Except camilina and fava bean meal, the other ingredients appear to be favorable for Seriola dumerili diets, especially the ones from animal sources. The lower case chemical score values (minimum value from AARs) were obtained in some vegetal ingredients (14 to $18 \%$ ), while the highest ones, appeared in marine ingredients (69 to $88 \%$ ). According to Oser's Index, the most balanced protein for yellowtail with regard to essential amino acids was in krill, defatted krill, and fishmeal (92 to 96\%). So, animal sources are suitable as protein ingredients, but they could be enhanced through some essential amino acid supplementation. 
In the last two decades the European aquaculture sector has shown an increasing

45

46

47

48

49

50

51

52

53

54

interest and demand in fast-growing species (Mazzola et al. 2000) such as

Mediterranean yellowtail ( $\underline{\text { Seriola }} \underline{\text { dumerili)}}$, as they can improve the competitiveness of aquaculture companies.

The most expensive component in feed formulation in aquaculture is protein.

This is especially important considering that Seriola species require high protein dietary levels (450550 $\left.\mathrm{g} \mathrm{kg}^{-1}\right)$ for maximum growth (Masumoto et al. 1998; Jover et al. 1999; Tomás et al. 2008), and the dietary substitution of proteins by other nutrients—such as lipids or carbohydrates - is not the best solution for the formulation of feeds for $\underline{\mathrm{S}}$. dumerili (Jover et al. 1999). In this sense, fishmeal is an ideal protein source for carnivorous fish, because it contains a balanced amino acid composition, high content of phosphorous and minerals and high digestibility coefficients. However, its high cost motivated its reduction in aqua feeds, while maintaining the same protein levels from alternative protein sources.

Currently, in order to avoid the dependence on fishmeal, aquaculture diets should contain high amounts of alternative proteins that are more widely available and that have lower and more stable market prices than this marine resource. Alternative proteins include a large range of plant or animal proteins with competitive prices (Martínez-Llorens, Vidal, \& Cerdá, 2012). Despite these economic advantages, previous results on Mediterranean yellowtail show that alternative proteins cannot totally replace fishmeal when they are used as the sole ingredient. When soybean is included to replace over $30 \%$ of the fishmeal, it resulted in poor growth and showed low nutrient efficiency (Tomás et al. 2005). Total fishmeal substitution presents some limitations in fish diets, such as the anti-nutrients that are particularly contained in vegetable proteins (Krogdahl et al. 2010), causing a protease enzyme activity decrease and, therefore, low protein 
digestibility (Monge-Ortiz et al. 2016). Another issue related to the use of alternative protein sources is the inadequate profile of amino acids (Cerezo et al. 2012), which results in poor fish growth and protein deficiencies. This forces the use of supplemental diets with synthetic amino acids, which increases the feed price. The best growth and nitrogen retention results when combination of protein sources are used, that include a combination of aminoacids in order to complement one source with limiting ones, that is the case of Sparus aurata (Kissil \& Lupatsch, 2004; Sánchez-Lozano et al., 2009), and evidence suggests that for other species too, like $\underline{\text { Salmo }} \underline{\text { salar }}$ (Espe, 2006) or Seriola dumerili (Monge-Ortiz et al, 2017). For this reason, the combination of animal proteins (such as defatted krill and poultry meal) with plant proteins in fish diets could be beneficial to palliate the deficiencies in amino acids of some protein sources, thus reducing the anti-nutrient compounds and avoiding supplementation with synthetic aminoacids (AAs), lack of palatability (Oliva-Teles 2012) and 'green liver' (Takagi et al. 2005). The adequate proportion to simulate the ideal amino acid profile in diets for the Mediterranean yellowtail will require studies on the digestibility and the protein quality of these ingredients.

Therefore, the evaluation of feed ingredients is crucial to nutritional research and feed development for aquaculture species (Glencross et al. 2007). The alternative protein sources and their inclusion levels need to be optimized in fish diets to make aquaculture production more efficient and cost-effective. Digestibility trials are essential to shed light on the potential of these ingredients for fish before their inclusion in diet formulations. 
94

95

96

97

digestibility coefficient (ADC) values of feed ingredients are normally the result of differences in species, changes in the harvest/catch season of the raw materials and conditions under which they were processed. For that reason, studies on various marine fish species have been conducted (Lupatsch et al. 1997; Tibbets et al.2004; Booth et al. 2005; Tibbets et al. 2006; Davies et al. 2009) in order to assess the quality value of different ingredients.

Taking into account the relevance of digestibility estimation for diet formulation, the aim of this present study was to compare the apparent nutrient digestibility and protein quality of 12 different commercially available ingredients for Seriola dumerili.

\section{Materials and Methods}

\section{$\underline{\text { Ingredients and Experimental Diets }}$}

Yellowtail (S. dumerili) juveniles were caught in the Mediterranean and transferred to the facilities of the Polytechnic University of Valencia, Spain.

Feed ingredients were tested for apparent protein digestibility, availability of digestible amino acids and protein quality in fishmeal, krill meal, squid meal, poultry meal (international feed number 5-03798), defatted krill meal (a product obtained by removing the fat with ethanol), soybean ( $\underline{\text { Glycine }} \underline{\max })$, wheat gluten (Triticum spp), camilina (Camelina sativa) (product given to our facilities by local farmers), pea (Pisum

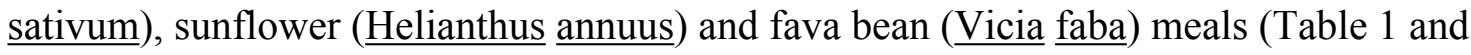

3). Test diets were prepared by mixing a basal diet with one of the test ingredients

(Table 2) in a ratio of 7 to 3, as described by Cho and Slinger (1979). 
116 The different ingredients of the diets were weighed individually and mixed to form

117 homogeneous dough, and were prepared by cooking-extrusion processing with a a semi-

118 industrial twin-screw extruder (CLEXTRAL BC-45, St. Etienne, France). The

119 conditions under which they were processed are as follows: a screw speed of $100 \mathrm{rpm}$, a

120 temperature of $110 \mathrm{C}$, and a pressure of 40-50 atm. The experimental diets were assayed

121 in quintuplicate. The fish were handfed once a day $(8.00 \mathrm{~h})$, and fecal collection

122 occurred $8 \mathrm{~h}$ later (16:00h). The pellet size used was $3 \mathrm{~mm}$ during the experiment,

123 increasing to $4 \mathrm{~mm}$ in the final part of the experiment. The pellets were slowly

124 distributed to give all fish time to eat. The uneaten diet was collected when fish had

125 finished feeding.

126

127

128

129

130

131

132

133

134

135

136

137

138

139

\section{Digestibility Assay}

Fifteen yellowtails $(175 \pm 2.8 \mathrm{~g}$ initial mean live weight) were randomly

distributed in five experimental tanks (190 L fiberglass tanks, $88 \mathrm{~cm}$ length, $62 \mathrm{~cm}$

diameter and $188 \mathrm{~cm}$ depth) of a marine semi-closed recirculating system designed on

the basis of the Guelph system (the fecal material being collected in a settling column).

Each tank was loaded with three fish. The velocity of the water flow was adjusted to

minimize settling of the feces in the drainpipe and maximize feces recovery in the settling column.

There was a three-month adaptation period (adaptation to dry diets was a very long process, in which yellowtail were first fed anchovy and, later, a semi-moist diet-a mix of anchovy and fishmeal— - before being fed the control diet). Once the fish had become accustomed to both the tanks and the dietary regime, collection of feces was initiated. 
The fish were fed one meal a day at $10.00 \mathrm{~h}$. The feed was offered only as long

as the fish were actively feeding in order to avoid wastage. One hour after the meal, the drainpipe and the settling column were brushed out to remove uneaten feed particles and feces from the system to avoid mixing feed particles and feces in the recollection.

Feces were collected next day from the base of the settling column into a plastic container by gravity at $8.00 \mathrm{~h}$. After feces collection, the fish were fed again at $10.00 \mathrm{~h}$, waiting two hours between feces recolection and feeding to avoid stress.

The water temperature was maintained around $20 \mathrm{C}(21.5 \pm 2.4 \mathrm{C})$ during the experimental period by a water conditioning pump (TRANE CAN 490, $123.3 \mathrm{~kW}$ ) installed in the system. All tanks were equipped with aeration and the level of dissolved oxygen was $6.6 \pm 1.3 \mathrm{mg} \mathrm{L}^{-1}$. Water salinity was $31.5 \pm 4.1 \mathrm{~g} / \mathrm{L}, \mathrm{pH} 7.3 \pm 0.4, \mathrm{NO}_{3}{ }^{-}$ $(25-150 \mathrm{mg} / \mathrm{L})$, and $\mathrm{NO}_{2}^{-}(0.05-0.5 \mathrm{mg} / \mathrm{L})$, and the ammonium value was undetectable The photoperiod was maintained at 12-h light and 12-h dark by means of artificial daylight simulation. All these parameters were measured daily from Monday to

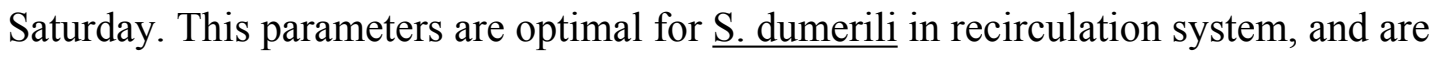
similar that in other Seriola experiments (Jover, 1999; Monge-Ortiz, 2018a, 2018b) Over a six-month period, the fish groups were fed the experimental diets and feces were sampled from each tank. One tank was fed with the control diet over six months to determine the possible variations in digestibility throughout the experimental period. Experimental periods were 14 days long for each diet and each replicate. The last three days of the two-week period fish fasted in order to avoid mixing feces between diets. Feces were removed immediately to determine their amount and have enough for analysis following which fish continued to be fed the same diet for another week. The switching of dietary treatments was as follows: diets with fava bean, camilina, soybean and pea meal were tested from Week 1 to Week 2, from 7 to 8 , from 
16513 to 14 and from 19 to 20 respectively; diets with sunflower, wheat, wheat gluten and 166 defatted krill meal were assayed from week 3 to week 4, from 9 to 10 , from 15 to 16 , 167 from 21 to 22 and from 25 to 26 , respectively; and diets containing fish, krill, meat and 168 squid meal were tested from Week 5 to 6 , from 11 to 12 , from 17 to 18 , from 23 to 24 , 169 and from 27 to 28 , respectively of the experimental trial.

170 The fecal material collected was dried to a constant weight in an oven at $60 \mathrm{C}$ for $48 \mathrm{~h}$ 171 prior to analysis and stored in airtight plastic containers until nutrient component and 172 inert marker (acid insoluble ash, AIA) analysis. The AIA content of feeds and feces was 173 determined by the method of Atkinson et al. (1984), to calculate the apparent 174 digestibility coefficient, (ADC).

175 Apparent digestibility coefficients $\left(\mathrm{ADC}_{\text {diet }}, \%\right)$ of each specific nutritional 176 variable (protein (ADCp, \%), lipid ( $\mathrm{ADCl}, \%)$, and $\mathrm{AA})$ of the diets were calculated 177 using the following formulae:

$$
\mathrm{ADC}_{\text {diet }}=1-\left(\frac{\text { Marker }_{\text {diet }} \times \text { Nutrient }_{\text {faeces }}}{\text { Marker faeces }_{\text {futrient }} \times \text { Niet }_{\text {dut }}}\right)
$$
the marker content of the diet and the feces, respectively, and Nutrient diet $\left(\mathrm{g} \mathrm{kg}^{-1}\right)$ and

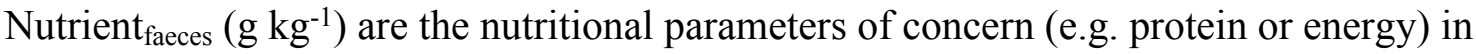
the diet and the feces, respectively. acids for the test ingredients (30\% replacement level) were calculated as follows:

$$
\mathrm{ADCN}_{\mathrm{ing}}=\frac{\left[(a+b) \times \mathrm{ADCN}_{\text {test }}-a \times \mathrm{ADCN}_{\mathrm{ref}}\right]}{b}
$$


In the equation above, " $a$ " is nutrient contribution of reference diet to nutrient

191

192

193

194

195

196

197

198

199

200

201

202

203

204

205

206

207

208

209

210

211

212

213

\section{$\underline{\text { Chemical Analysis }}$}

Chemical analysis of the dietary ingredients was performed prior to diet formulation (Table 1). Diets and their ingredients were analyzed according to AOAC (1995) procedures: dry matter (105 C to constant weight), ash (incinerated at $550 \mathrm{C}$ to constant weight), crude protein ( $\mathrm{N}$ x 6.25), assessed by the Kjeldahl method after acid digestion (Kjeltec 2300 Auto Analyser, Tecator Höganas, Sweden), and crude lipid, extracted with methyl-ether (Soxtec 1043 extraction unit, Tecator).

Following the aforementioned method by Bosch et al. (2006), the amino acid content of the fish carcasses and the diets were established using a Waters HPLC system (Waters 474, Waters, Milford, MA, USA) with two pumps (Model 515, Waters), an auto-sampler (Model 717, Waters), a fluorescence detector (Model 474, Waters) and a temperature control module. Before hydrolysation, alpha aminobutyric acid was added as an internal standard. The derivatization of amino acids was made by using AQC (6aminoquinolyl-N-hydroxysuccinimidyl carbamate). Methionine and cysteine were determined separately as methionine sulphone and cysteic acid after oxidation with performic acid. Amino acids were separated with a C-17 reverse-phase column Waters Acc. Tag $(150 \mathrm{~mm}$ x $3.9 \mathrm{~mm})$ and subsequently transformed to Met and Cys. 
The values of the following indices were calculated:

216

- Amino acid ratio $(\mathrm{AAR}, \%)=\left(\mathrm{AA}_{\text {sample }}\right) /\left(\mathrm{AA}_{\text {reference }}\right) * 100$, where $\mathrm{AA}_{\text {sample }}$ and

$\mathrm{AA}_{\text {reference }}$ are the digestible amino acid contents in the test sample and whole $\underline{\mathrm{S}}$.

dumerili (Fig. 1), the one taken as reference (average values of 20 samples of fish weighing 100 to $500 \mathrm{~g}$ ).

220

- Chemical score (CS, \%): minimum value from AARs calculated for digestible

essentials amino acids (EAA: Arg, His, Ile, Leu, Lys, Met, Phe, Thr, Val).

- Limiting amino acid: the digestible amino acid corresponding to CS in the test sample.

- Oser's Index (OI, \%): used as index of nutritional quality and achieved as the

geometric mean ratio of digestible amino acids in samples of the ones detected in

$\underline{\text { Seriola dumerili, which were taken as a reference according to the following formula: }}$

OI $(\%)=\left(10^{\left(1 / n^{*}(\log (A A R 1)+\log (A A R 2) \ldots+\log (A A R n))\right.}\right)$

in which $\mathrm{AAR}_{1}, \mathrm{AAR}_{2}, \ldots \mathrm{AAR}_{\mathrm{n}}$ are the ratios of digestible essential amino acids, and " $n$ " is the number of detected digestible essential amino acids. When the ratio lay above 100, this was taken as reference (Oser 1951).

\section{$\underline{\text { Statistical Analysis }}$}

Digestibility coefficients were evaluated using one-way analysis of variance (ANOVA). ACD data were $\log _{10}$ transformed to meet the assumptions of statistical tests

234 (normality, linearity and homosdasticity). The Newman-Keuls test was used to assess specific differences among diets at a level of $\mathrm{P}<0.05$ (Statgraphics, Statistical Graphics 


\section{Results}

1. The greatest protein values were observed in animal meals; fishmeal (713.2 $\left.\mathrm{g} \mathrm{kg}^{-1}\right)$

242 wheat gluten (810 g kg-1), squid meal (718.8 g kg-1) and extracted krill meal (723.1 g

$243 \mathrm{~kg}-1)$, while the lowest were found in vegetable meas like pea (215.9 $\mathrm{g} \mathrm{kg}-1)$, fava bean

244 (236.6 g kg-1) and sunflower meal (291.3 g kg-1).

deficiencies in EAA, such as in arginine, threonine, lysine and methionine (Table 3).

Arginine, lysine and leucine were the predominant essential amino acids in animal principal non-essential amino acids present in animal and vegetal meals were aspartate and glutamine.

\section{Digestibility}

The ADCs of dry matter for yellowtail ranged from 71.88 to $89.53 \%$ for animal ingredients, and from 65.89 to $79.98 \%$ for plant products. The higer protein ADCs appeared in fishmeal (91.3\%), wheat gluten (87\%), defatted krill meal (86.7\%), squid meal $(85.2 \%)$ and poultry meal $(85.0 \%)$; mid-range in krill meal $(75.8 \%)$, soybean meal

256 (73.2\%) and sunflower and pea meal (63\%); and low in camilina (48.5\%) and fava bean 257 meal $(54.9 \%)$

Apparent digestibility coefficients of lipids in all the treatments were above $88 \%$, except in the case of pea meal $(83.5 \%)$. 
For the animal ingredientss, the availabilities of amino acids (Table 5) in fish,

261

262

263

264

265

266

267

268

269

270

271

272

273

274

275

276

277

278

279

280

281

282

283

squid, meat and defatted krill meal were generally higher than those in krill meal.

Among all the plant ingredients, the availabilities of amino acids in wheat gluten were

the highest, followed by soybean-, pea- and sunflower meal. Camilina and bean meal presented the lowest AAs ADC.

\section{$\underline{\text { Protein Quality Evaluation }}$}

Defatted krill meal was the most balanced digestible protein ingredient (Figs. 1, 2). It was only deficient in histidine, threonine and valine (AAR: 70 (CS), 86 and 87\%). Fishmeal was slightly deficient in isoleucine, leucine, lysine, phenylalanine and valine (AAR: 90, 94, 95, 97 and $88 \%$, respectively). Krill meal was deficient in histidine, lysine and valine (AAR inferior to $90 \%$ ). Squid and poultry meals presented 60 to $85 \%$ ARRs in all the digestible amino acids, except for arginine, which was the most balanced of them all, while isoleucine was the least balanced (AAR $<50 \%$ ). With respect to the vegetal ingredients, wheat gluten showed the lowest CS (13.98\% for lysine), followed by sunflower, which was found to be deficient in Met (CS: 17.97\%), and camilina meal (poor in methionine, CS 30.8\%). Pea meal proved to be a balanced amino acid ingredient (its CS, Met, was above 50\%).

Oser's Index (OI, Fig. 2) calculated for protein meals was positively related with CS, presenting the lowest values of OI those presented the lowest CS, such in the case of wheat meal and sunflower meal (50.41\% OI, $13.89 \%$ CS and $67.96 \%$ OI, $17.97 \%$ CS respectively). On the contrary, defatted krill and fishmeal (92 to $96 \%$ ) showed the most balanced protein with regard to essential amino acids, whereas all the other ingredients presented lower levels (50-78\%). 
The results obtained in the present study confirmed the very high digestibility of

285

286

287

288

289

290

291

292

293

294

295

296

297

298

299

300

301

302

303

304

305

306

307

308

certain animal proteins for carnivorous marine fish (Lupatsch et al., 1997; Tibbets et al. 2006). ADCs of animal proteins were close to those obtained for fishmeal concerning crude protein digestibility, and that fact is probably the result of their very high protein concentrations. Only krill meal ADCp was lower than the other animal protein sources, probably because of the unusually high amount of fat of the krill meal sample used in this study (and consequent low protein level). This was the main difference between the krill meal and the defatted krill meal, which has a lower fat and a higher protein level, making it a higher quality product for yellowtail diets. Tibbetts (2006) obtained similar results with shrimp, with low ADC, due to the high ash content of the shrimp meal.

Protein ADCs of fishmeal assessed in yellowtail are also similar to the ones encountered in turbot ( $\underline{\text { Psetta }} \underline{\text { maxima }})$, seabass (Dicentrarchus labrax $)$, sea bream ( $\underline{\text { Sparus }} \underline{\text { aurata)}})$ Atlantic cod ( $\underline{\text { Gadus }} \underline{\text { morhua }})$, red drum (Sciaenops ocellatus),

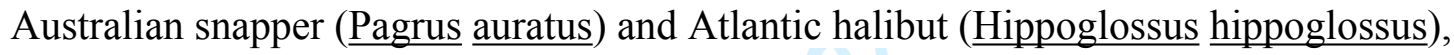
at 91 to 96\% (Gaylord and Gatlin 1996; Lupatsch et al. 1997; Gomes da Silva and Oliva-Teles 1998; Burel et al. 2000; Peach 2005; Tibbetts et al. 2006; Davies et al. 2009; Booth et al. 2010).

Protein ADCs were high for poultry meal (85\%). Animal by-product meals can vary greatly in their proximate composition, depending on several factors (raw material source and freshness, production processes and storage) and, due to its very nature, the values reported for protein ADCs are also highly variable in studies on fish. In many fish species, poultry meal has received positive results in diets (ADCp 85.5\% in sea bass, 79 to $80 \%$ in sea bream, $78.4 \%$ in turbot, and $80 \%$ in Atlantic cod), and is regarded as the most effective animal protein (Lupatsch et al. 1997; Tibbetts et al. 2006; Davies et al. 2009). 
Atlantic cod (Tibbetts et al. 2006) was nearly $100 \%$, very different indeed to the krill

ADCp in yellowtail (76\%), but that krill meal was obtained through finely grinding

whole krill that had previously been freeze-dried (Euphausia superba) and, therefore, the proximate composition was fairly different from the one found in commercially produced krill meals like the one used in the present work. Those discrepancies are explained by the differences in product quality, as in the case of the defatted krill meal (full-fat krill meal) with a higher protein level.

There are numerous studies on digestibility of soybean meal on various fish species. The protein ADC, however, varied a great deal (76 to 98\%). Yellowtail is within this range, although on the lower side, i.e. among the species that present a lower soybean protein digestibility. Other authors observed a decrease in protein digestibility (Robaina et al. 1995; Refstie et al. 1999), mainly attributed to the presence of phytate.

Pea meal had a middle ADCp. This ingredient appears to have some potential for its use in marine fish diets (Sánchez-Lozano et al. 2009, 2011); nonetheless it should be pre-extruded in order to boost the digestibility of non-protein ingredients. well digested by Seriola dumerili. There were only slight differences in this parameter 
333 between soybean meal and most of the raw materials. Several studies have concluded 334 that dietary soybean meal decreases the lipid digestibility in salmonids (Romarheim et 335 al. 2008). This fact must be attributed to the bile acid level, which is reduced by dietary 336 soybean meal (Romarheim et al. 2006; Yamamoto et al. 2007).

Regarding the availability of AAs, it should be noted that the digestibility of each AA within a feed ingredient is variable. This variability, nonetheless, increases in those ingredients with a lower protein ADC (AAs ADC of camilina or fava bean meals were between 38 and 66\%). In general, apparent digestibility coefficients of AAs reflect the apparent CP digestibility coefficients of some test ingredients. In some of them, however, there are differences, like in wheat gluten, in which apparent digestibility coefficients of AAs were lower than ADCp. On the contrary, krill meal, pea meal or poultry meal presented higher AA ADCs. Thus, amino acid availabilities cannot always be estimated from the ingredient ADCp. Fishmeal and defatted krill meal are the most balanced digestible amino acid ingredients and have one advantage: they benefit from having a higher protein content and CS than krill. However, the defatted krill meal also has one shortcoming: the need for histidine supplementation. Regarding other animal sources, squid meal was the most balanced amino acid in arginine and poultry meal 350 protein quality was similar to camilina and soybean meal.

Despite the high protein digestibility observed in present work for some protein

352 meals, the biological value of the protein should also be taken into account before diet

353 formulation to include them in fish diets. For example, wheat gluten digestibility

354 resulted very high, however it shows a low OI and the lowest CS (in this case Lysine)

355 and therefore it cannot replace the fishmeal in high dietary levels for Mediterranean 356 yellowtail feeding. 
It has been observed in studies performed with sea bream (Lupatsch et al. 1997)

that, when using ACDp values obtained for individual ingredients to calculate the

$\mathrm{ACDp}$ for compounds diets, both values were very similar, and consequently, protein

digestibility can be considered to be additive. Therefore, ACDp results obtained in this

present experiment, along with the protein quality assessments, should be taken into

account for formulating diets for Mediterranean yellowtail. This is a useful tool to

simulate the ideal protein in diets because, by combining different ingredients, the

inclusion of synthetic amino acids could be avoided or diminished, which would reduce

the cost of fish diets and improve protein digestion.

In conclusion, animal sources are evidently suitable as protein ingredients in

yellowtail diets, although the protein quality indices present in them could be enhanced

through some essential amino acid supplementation. None of the vegetal meals assayed

could offer a good nutritional balance on their own and, therefore, they would either

need to be supplemented or need to be used together with other raw materials.

Project financed by the "Ministerio de Ciencia e Innovación" (reference AGL2011fish used in the present study. 


\section{Literature Cited}

381

382

383

384

385

386

387

388

389

390

391

392

393

394

395

396

397

398

399

400

401

402

AOAC. 1995. Official Methods of Analysis of the Association of Official Analytical Chemists 16th Edition (16th ed.)AOAC Inc., Arlington, Virginia, USA

Atkinson J.L., Hilton J.W. and S.J. Slinger. 1984. Evaluation of acid insoluble ash as

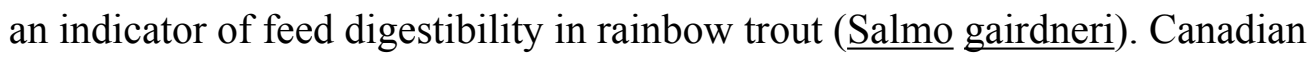
Journal of Fisheries and Aquatic Sciences, 41:1384-1386

Booth M.A., Allan G.L. and A.J. Anderson. 2005. Investigation of the nutritional requirements of Australian snapper Pagrus auratus (Bloch \& Schneider, 1801): apparent digestibility of protein and energy sources. Aquaculture Research, $36: 378-390$

Booth M.A., Allan G.L. and I. Pirozzi. 2010. Estimation of digestible protein and energy requirements of yellowtail kingfish Seriola lalandi using a factorial approach. Aquaculture, 307:247-259.

Bosch L., Alegria A. and R. Farré. 2006. Application of the 6-aminoquinolyl-Nhydroxysuccinimidyl carbamate (AQC), reagent to the RP-HPLC determination of amino acids in infant foods. Journal of chromatography. B, Analytical technologies in the biomedical and life sciences, 831:176-178.

Bureau, D.P., Harris, A.M. and Cho, C.Y. 1999. Apparent digestibility of rendered animal protein ingredients for rainbow trout (․ㅡcorhynchus $\underline{\text { mykiss)}}$. Aquaculture, 180: 345-358.

Burel C., Boujard T., Tulli F. and S.J. Kaushik. 2000. Digestibility of extruded peas, extruded lupin and rapeseed meal in rainbow trout ( $\underline{\text { Oncorhynchus mykiss }}$ ) and turbot (Psetta maxima). Aquaculture, 188:285-298 
403

404

405

406

407

408

409

410

411

412

413

414

415

416

417

418

419

420

421

422

423

424

425

Cerezo Valverde J., Martínez-Llorens S., Tomás Vidal A., Jover M., Rodríguez C., Estefanell J., Gairín J.I., Domingues P.M., Rodríguez C.J. and B. García. 2012. Amino acids composition and protein quality evaluation of marine species and meals for feed formulations in cephalopods. Aquaculture International, $21: 413-433$

Cho C. Y. and S.J. Slinger. 1979. Apparent digestibility measurement in feedstuffs for rainbow trout, Pages 239-247 in J. Halver, K. Tiews (Eds.), Proc. World Symp. on Finfish Nutrition and Fishfeed Technology, vol. 2 Heenemann, Berlin.

Davies J., Gouveia A., Laporte J., Woodgate S. and S. Nates. 2009. Nutrient digestibility profile of premium (category III grade) animal protein by-products for temperate marine fish species (European sea bass, gilthead sea bream and turbot). Aquaculture Research, 40:1759-1769.

Forster I. 1999. A note on the method of calculating digestibility coefficients of nutrients provided by single ingredients to feeds of aquatic animals. Aquaculture Nutrition, 5:143-145.

Gaylord T.G. and D.M. Gatlin. 1996. Determination of digestibility coefficients of various feedstuffs for red drum ( $\underline{\text { Sciaenops ocellatus) }}$. Aquaculture, 139:303-314.

Glencross B.D., Booth M. and G.L. Allan. 2007. A feed is only as good as its ingredients - a review of ingredient evaluation strategies for aquaculture feeds. Aquaculture Nutrition, 13:17-34.

Gomes da Silva J. and A. Oliva-Teles. 1998. Apparent digestibility coefficients of feedstuffs in seabass (Dicentrarchus labrax) juveniles. Aquatic Living Resources, 11:187-191. 
Jover M., García-Gómez A., Tomás A., De la Gándara F. and L. Pérez. 1999. Growth of the Mediterranean yellowtail ( containing different levels of protein and lipid. Aquaculture, 179:25-33.

Krogdahı Å., Penn M., Thorsen J., Refstie S. and A.M. Bakke. 2010. Important antinutrients in plant feedstuffs for aquaculture: an update on recent findings regarding responses in salmonids. Aquaculture Research, 41:333-344.

\section{Lupatsch I., Kissil G., Sklan, D. and E. Pfeffer. 1997. Apparent digestibility} coefficients of feed ingredients and their predictability in compound diets for gilthead seabream, Sparus aurata L. Aquaculture Nutrition, 3:81-89.

Martínez-Llorens, S., Vidal, A. T. and M.J. Cerdá. 2012. A new tool for determining the optimum fish meal and vegetable meals in diets for maximizing the economic profitability of gilthead sea bream (Sparus aurata, L.) feeding. Aquaculture Research, 43:1697-1709.

Masumoto T., Itoh Y., Ruchimat T., Hosokawa H. and S. Shimeno. 1998. Dietary amino acids budget for juvenile yellowtail (Seriola quinqueradiata). Bulletin of Marine Science and Fisheries, 18:33-37.

Mazzola, A., Favaloro, E. and G.L. Sarà. 2000. Cultivation of the Mediterranean amberjack, Seriola dumerili (Risso, 1810), in submerged cages in the Western Mediterranean Sea. Aquaculture, 181:257-268.

\section{Monge-Ortiz R., Martínez-Llorens S., Márquez L., Moyano F.J., Jover-Cerdá M.} and A. Tomás-Vidal. 2016. Potential use of high levels of vegetal proteins in diets for market-sized gilthead sea bream (모us $\underline{\text { aurata) }}$. Archives of Animal Nutrition, 70 http://dx.doi.org/10.1080/1745039X.2016.1141743 


\section{Monge-Ortiz R., Tomás-Vidal A., Rodriguez-Barreto D., Martínez-Llorens S.,} Pérez J.A., Jover-Cerdá M., Lorenzo A. 2018. Replacement of fish oil with

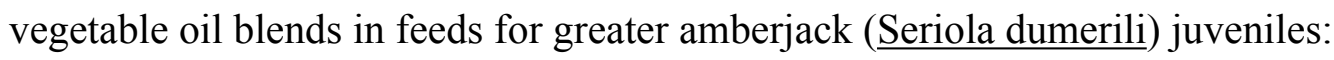
Effect on growth performance, feed efficiency, tissue fatty acid composition and flesh nutritional value. Aquculture Nutrition. 24:605-615.

\section{Monge-Ortiz R., Tomás-Vidal A., Gallardo-Álvarez F.J., Estruch G., Godoy-} Olmos S., Jover-Cerdá M., Martínez-Llorens S. 2018. Partial and total replacement of fishmeal by a blend of animal and plant proteins in diets for

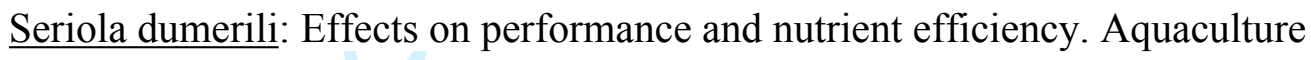
Nutrition, 24:1163-1174.

Oliva-Teles A. 2012. Nutrition and health of aquaculture fish. Journal of Fish Diseases, $35: 83-108$.

Oser B.L. 1951. Methods for integrating essential amino acid content in the nutritional evaluation of protein. Journal of the American Dietetic Association, 27:396-402.

Peach R.W. 2005. Protein and energy utilization by juvenile Atlantic halibut ( Scotia Agricultural College, Truro, Nova Scotia.

Refstie S., Svihus B., Shearer K.D. and Storebakken, T. 1999. Nutrient digestibility in Atlantic salmon and broiler chickens related to viscosity and non-starch polysaccharide content in different soybean products. Animal Feed Science and Technology, 79:331-345.

\section{Robaina L., Izquierdo M.S., Moyano F.J., Socorro J., Vergara J.M., Montero D.} and H. Fernández-Palacios. 1995. Soybean and lupin meals as protein sources in 
472

473

474

475

476

477

478

479

480

481

482

483

484

485

486

487

488

489

490

491

492

diets for gilthead sea bream ( $\underline{\text { Sparus }} \underline{\text { aurata)}}$ : nutritional and histological implications. Aquaculture, 130:219-233.

Robaina L., Corraze G., Aguirre P., Blanc D., Melcion J.P. and S. Kaushik. 1999. Digestibility, postprandial ammonia excretion and selected plasma metabolites in European sea bass (Dicentrarchus labrax) fed pelleted or extruded diets with or without wheat gluten. Aquaculture, 179:45-56.

Romarheim O.H., Skrede A., Gao Y., Krogdahl Å., Denstadli V., Lilleeng E. and T. Storebakken. 2006. Comparison of white flakes and toasted soybean meal partly replacing fishmeal as protein source in extruded feed for rainbow trout (Oncorhynchus mykiss). Aquaculture, 256:354-364.

Romarheim O.H., Skrede A., Penn M., Mydland L.T., Krogdahl A. and T. Storebakken. 2008. Lipid digestibility, bile drainage and development of

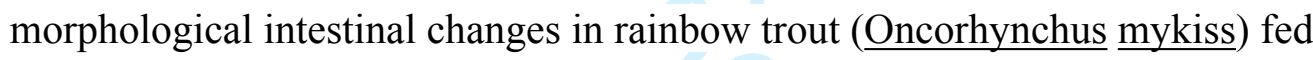
diets containing defatted soybean meal. Aquaculture, 274:329-338

\section{Sánchez-Lozano N.B., Martínez-Llorens S., Tomás-Vidal A. and M. Jover Cerdá.} 2009. Effect of high-level fishmeal replacement by pea and rice concentrate protein on growth, nutrient utilization and fillet quality in gilthead sea bream ( Sparus aurata, L.). Aquaculture, 298:83-89.

\footnotetext{
Sánchez-Lozano N., Martínez-Llorens S., Tomás-Vidal A. and M. Jover-Cerdá. 2011. Amino acid retention of gilthead sea bream (ㅁarus aurata, L.) fed with pea protein concentrate. Aquaculture Nutrition, 17:e604-e614.
} 
493 Tibbetts S.M., Lall S.P. and J.E. Milley. 2004. Apparent digestibility of common feed 494

495 ingredients by juvenile haddock, Melanogrammus aeglefinus. L. Aquaculture Research, 35:643-651.

496

497

498

499

500

501

502

503

504

505

506

507

508

509

510

511

512

Tibbetts S.M., Milley J.E. and S.P. Lall. 2006. Apparent protein and energy digestibility of common and alternative feed ingredients by Atlantic cod, Gadus morhua (Linnaeus, 1758). Aquaculture, 261:1314-1327.

Tomás A., De la Gándara F., García-Gómez A., Pérez, L. and M. Jover. 2005. Utilization of soybean meal as an alternative protein source in the Mediterranean yellowtail, Seriola dumerili. Aquaculture Nutrition, 11:333-340.

Tomás A., De la Gándara F., García-Gómez A. and M.J. Cerdá. 2008. Effect of the protein/energy ratio on the growth of Mediterranean yellowtail (Seriola dumerili). Aquaculture Research, 39:1141-1148.

Takagi S., Murata H., Goto T., Ichiki T., Munasinghe D.M., Endo M., Matsumoto T., Sakurai A., Hatate H., Yoshida T., Sakai T., Yamashita H., Ukawa M. and T. Kuramoto. 2005. The green liver syndrome is caused by taurine deficiency in Yellowtail, Seriola quinqueradiata fed diets without fishmeal. Aquaculture Science, 53:279-290.

\section{Yamamoto T., Suzuki N., Furuita H., Sugita T., Tanaka N. and T. Goto. 2007.} Supplemental effect of bile salts to soybean meal-based diet on growth and feed utilization of rainbow trout Oncorhynchus mykiss. Fisheries Science, 73:123-131 
513 TABLE 1. Proximate composition of ingredients used in the digestibility trial (expressed as $g \mathrm{~kg}^{-1}$ of dry matter basis, dm).

\begin{tabular}{|c|c|c|c|c|c|}
\hline Ingredients $^{\mathrm{a}}\left(g \mathrm{~kg}^{-1}\right)$ & Dry matter & Crude Protein & Crude lipid & Ash & N-free extract \\
\hline \multicolumn{6}{|l|}{ Plant protein ingredients } \\
\hline Fava bean meal & 890 & 237 & 12 & 33 & 718 \\
\hline Camilina meal & 918 & 391 & 45 & 61 & 503 \\
\hline Soybean meal & 882 & 499 & 22 & 71 & 408 \\
\hline Pea meal & 866 & 216 & 10 & 39 & 736 \\
\hline Sunflower meal & 896 & 291 & 15 & 67 & 627 \\
\hline Wheat meal & 890 & 116 & 15 & 18 & 851 \\
\hline Wheat gluten & 933 & 810 & 9 & 9 & 173 \\
\hline \multicolumn{6}{|c|}{ Animal protein ingredients } \\
\hline Defatted krill meal & 878 & 723 & 24 & 102 & 151 \\
\hline Fish meal & 903 & 713 & 93 & 168 & 26 \\
\hline Krill meal & 888 & 561 & 225 & 104 & 111 \\
\hline Poultry meal & 970 & 531 & 153 & 269 & 47 \\
\hline
\end{tabular}


Squid meal

928

719

30

110

142

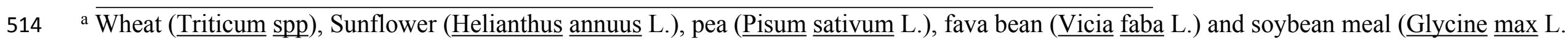

515 Merr.) were provided by DESCO, Museros, Valencia (Spain); Defatted krill meal was provided by LUDAN RENEWABLE ENERGY, Valencia

516 (Spain); Wheat gluten and Camilina (Camelina sativa, L. Crantz) were provided by DADELOS AGRÍCOLA, Valencia (Spain); Poultry meal was 517 provided by VALGRA S.A., Beniparrell, Valencia (Spain); Krill meal was provided by AKER SEAFOODS ANTATARCTIC, S. A. Lysaker 518 (Norway); Squid meal was provided by MAX NOLLERT, Utrecht (Netherlands). 
TABLE 2. Formulation and apparent digestibility coefficients of the experimental diets.

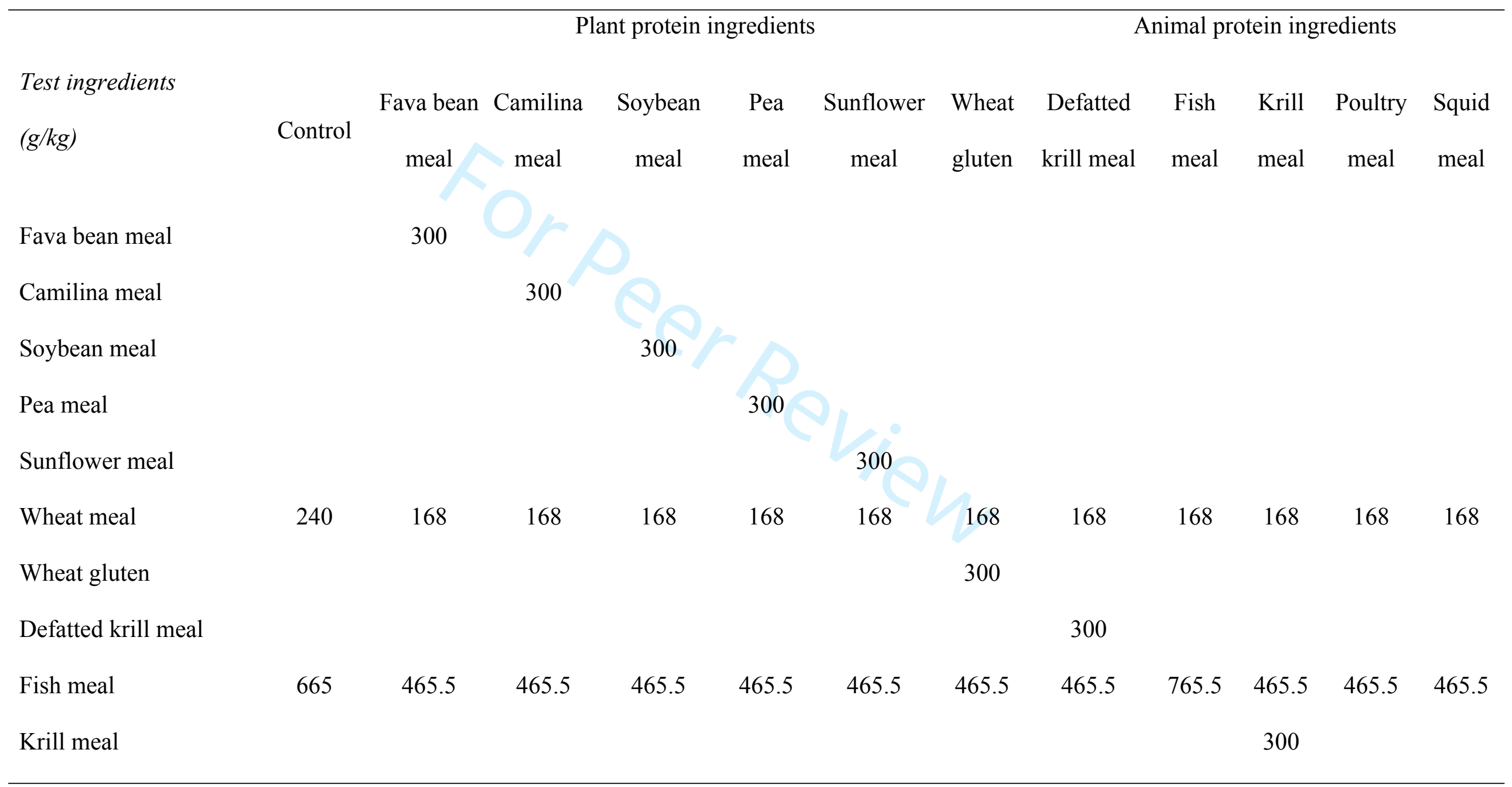




\begin{tabular}{|c|c|c|c|c|c|c|c|c|c|c|c|c|}
\hline Poultry meal & & & & & & & & & & & 300 & \\
\hline Squid meal & & & & & & & & & & & & 300 \\
\hline Fish oil & 75 & 52.5 & 52.5 & 52.5 & 52.5 & 52.5 & 52.5 & 52.5 & 52.5 & 52.5 & 52.5 & 52.5 \\
\hline $\begin{array}{l}\text { Multivitamin and } \\
\text { mineral mix }\end{array}$ & 20 & 14 & 14 & 14 & 14 & 14 & 14 & 14 & 14 & 14 & 14 & 14 \\
\hline Crude Protein (\% w.w.) & 46.2 & 37.4 & 41.3 & 40.3 & 35.8 & 37.4 & 55.2 & 56.0 & 53.0 & 45.4 & 51.3 & 49.5 \\
\hline Crude Lipids (\% w.w.) & 12.2 & 9.0 & 10.1 & 8.8 & 8.7 & 9.0 & 9.0 & 13.0 & 13.9 & 13.8 & 14.8 & 10.9 \\
\hline AIA ( $g \mathrm{~kg}^{-1}$ dry matter) & 2.2 & 2.2 & 3.1 & 3.1 & 2.8 & 1.6 & 1.8 & 2.0 & 3.5 & 3.4 & 3.6 & 3.0 \\
\hline Dry matter ADC (\%) & 84.8 & 72.1 & 76.4 & 75.8 & 76.5 & 78.9 & 84.1 & 78.6 & 83.9 & 76.6 & 80.2 & 81.0 \\
\hline Protein ADC (\%) & 96.9 & 85.8 & 83.6 & 90.4 & 88.5 & 90.2 & 94.5 & 93.5 & 97.5 & 90.0 & 93.8 & 96.1 \\
\hline Lipid ADC (\%) & 98.5 & 96.2 & 97.5 & 94.9 & 96.1 & 97.2 & 98.2 & 96.6 & 98.2 & 96.8 & 98.1 & 96.7 \\
\hline
\end{tabular}


TABLE 3. Amino acid composition of ingredients (expressed as $\mathrm{g} \mathrm{kg}^{-1}$ of dry matter basis, dm).

\begin{tabular}{|c|c|c|c|c|c|c|c|c|c|c|c|c|}
\hline \multirow{5}{*}{$E A A^{a}\left(g_{k g}^{-1}\right)$} & \multicolumn{7}{|c|}{ Plant protein ingredients } & \multicolumn{5}{|c|}{ Animal protein ingredients } \\
\hline & \multirow[b]{2}{*}{ Fava bean } & \multirow[b]{2}{*}{ Camilina } & \multirow{2}{*}{ soybean } & \multirow[b]{2}{*}{ Pea } & \multirow[b]{2}{*}{ Sunflower } & \multirow[b]{2}{*}{ Wheat } & \multirow[b]{2}{*}{ Wheat } & \multirow[b]{2}{*}{ Defatted } & \multirow[b]{2}{*}{ Fish } & \multicolumn{3}{|c|}{ Poultr } \\
\hline & & & & & & & & & & Krill & $\mathrm{y}$ & Squid \\
\hline & meal & meal & meal & meal & meal & meal & gluten & krill meal & meal & meal & meal & meal \\
\hline & & & & & & & & & & & & \\
\hline Arginine & 17.7 & 36.7 & 32.3 & 15.2 & 27.7 & 4.6 & 25.7 & 53.9 & 60.5 & 42.2 & 37.2 & 63.3 \\
\hline Histidine & 6.6 & 10.3 & 12.5 & 5.0 & 8.4 & 2.4 & 14.5 & 13.0 & 29.1 & 12.8 & 10.8 & 12.0 \\
\hline Isoleucine & 9.2 & 15.1 & 20.5 & 8.5 & 14.7 & 3.6 & 30.1 & 34.2 & 32.2 & 32.5 & 10.1 & 15.2 \\
\hline Leucine & 18.1 & 28.6 & 37.2 & 15.4 & 24.7 & 6.7 & 57.9 & 57.5 & 55.5 & 47.4 & 26.2 & 32.6 \\
\hline Lysine & 17.0 & 17.9 & 30.5 & 16.6 & 13.7 & 3.2 & 12.1 & 58.0 & 56.9 & 38.4 & 25.6 & 33.8 \\
\hline Methionine & 2.8 & 3.2 & 8.1 & 3.1 & 1.8 & 6.3 & 8.8 & 17.5 & 20.2 & 16.8 & 7.5 & 8.4 \\
\hline Phenylalanine & 9.8 & 19.1 & 23.0 & 9.6 & 16.2 & 4.5 & 43.1 & 33.2 & 30.8 & 30.3 & 15.8 & 15.5 \\
\hline Threonine & 8.3 & 16.9 & 17.5 & 7.5 & 13.0 & 3.2 & 19.5 & 31.1 & 34.2 & 27.8 & 16.8 & 18.0 \\
\hline Valine & 10.1 & 22.4 & 20.3 & 9.2 & 18.0 & 4.7 & 32.6 & 35.6 & 37.6 & 31.7 & 17.6 & 23.6 \\
\hline
\end{tabular}




\begin{tabular}{|c|c|c|c|c|c|c|c|c|c|c|c|c|}
\hline \multicolumn{13}{|c|}{$N E A A^{b}\left(\mathrm{~g} \mathrm{~kg}^{-1}\right)$} \\
\hline Alanine & 9.8 & 18.8 & 19.0 & 8.3 & 14.8 & 3.5 & 20.0 & 41.4 & 45.8 & 33.1 & 36.8 & 52.6 \\
\hline Aspartate & 25.9 & 39.4 & 57.7 & 23.6 & 43.6 & 5.4 & 22.3 & 81.0 & 65.1 & 60.3 & 50.8 & 46.0 \\
\hline Cystine & 2.1 & 4.5 & 4.1 & 2.0 & 2.9 & 7.1 & 11.2 & 3.5 & 6.6 & 3.8 & 7.3 & 35.8 \\
\hline Glutamine & 41.3 & 76.8 & 94.1 & 36.7 & 74.9 & 28.9 & 319.8 & 110.5 & 92.2 & 75.2 & 69.9 & 102.6 \\
\hline Glycine & 10.2 & 23.3 & 18.6 & 8.4 & 20.2 & 4.7 & 24.5 & 30.6 & 48.3 & 27.8 & 75.4 & 106.9 \\
\hline Proline & 8.9 & 22.7 & 21.7 & 7.4 & 16.0 & 9.4 & 108.2 & 23.8 & 29.7 & 23.0 & 42.7 & 53.6 \\
\hline Serine & 12.1 & 17.3 & 24.2 & 9.6 & 15.4 & 4.9 & 36.7 & 29.1 & 29.9 & 24.8 & 22.8 & 22.9 \\
\hline Tyrosine & 4.2 & 9.7 & 12.4 & 3.5 & 6.7 & 1.3 & 22.9 & 29.3 & 23.0 & 27.3 & 11.2 & 11.8 \\
\hline $\begin{array}{c}\text { Ratio } \\
\text { EAA/NEAA }\end{array}$ & 0.87 & 0.80 & 0.80 & 0.91 & 0.71 & 0.60 & 0.43 & 0.96 & 1.05 & 1.02 & 0.53 & 0.51 \\
\hline
\end{tabular}

523 aAA: Essential amino acids.

524 bNEAA: Non-essential amino acids. 


\begin{tabular}{|c|c|c|c|c|c|c|c|c|c|c|c|c|}
\hline \multirow[b]{2}{*}{$\mathrm{ADC}(\%)$} & \multicolumn{6}{|c|}{ Plant protein ingredients } & \multicolumn{5}{|c|}{ Animal protein ingredients } & \multirow[b]{2}{*}{ SEM $^{\mathrm{a}}$} \\
\hline & Fava & Camilina & Soybean & Pea & Sunflowe & Wheat & Defatted & Fish & Krill & Poultr & Squid & \\
\hline & bean & meal & meal & meal & r meal & gluten & krill meal & meal & meal & $\mathrm{y}$ & meal & \\
\hline & meal & & & & & & & & & meal & & \\
\hline Dry matter & $42.2^{\mathrm{d}}$ & $58.8^{\mathrm{c}}$ & $54.9^{\mathrm{c}}$ & $57.2^{\mathrm{c}}$ & $65.7^{\mathrm{c}}$ & $82.2^{\mathrm{ab}}$ & $68.0^{\mathrm{c}}$ & $87.2^{\mathrm{a}}$ & $57.7^{\mathrm{c}}$ & $70.2^{\mathrm{bc}}$ & $70.1^{\mathrm{bc}}$ & 3.4 \\
\hline Protein & $54.9^{d}$ & $48.5^{\mathrm{e}}$ & $73.2^{\mathrm{c}}$ & $63.0^{\mathrm{d}}$ & $62.9^{\mathrm{d}}$ & $87^{b}$ & $86.7^{\mathrm{b}}$ & $91.3^{\mathrm{a}}$ & $75.8^{\mathrm{c}}$ & $85.0^{\mathrm{b}}$ & $85.2^{\mathrm{b}}$ & 1.3 \\
\hline Lipid & $90.2^{\mathrm{ab}}$ & $91.3^{\mathrm{ab}}$ & $91.1^{\mathrm{ab}}$ & $83.5^{\mathrm{c}}$ & $94.0^{\mathrm{a}}$ & $90.8^{\mathrm{ab}}$ & $88.4^{\mathrm{b}}$ & $94.2^{\mathrm{a}}$ & $92.0^{\mathrm{ab}}$ & $93.9^{\mathrm{a}}$ & $88.3^{\mathrm{b}}$ & 1.2 \\
\hline
\end{tabular}

TABLE 4. Apparent digestibility coefficients (ADCs) for dry matter, crude protein and crude lipid in test ingredient consumed by yellowtail.

.


TABLE 5. Apparent digestibility coefficients (ADCs) of amino acids in test ingredient consumed by yellowtail.

\begin{tabular}{|c|c|c|c|c|c|c|c|c|c|c|c|c|}
\hline \multirow{3}{*}{$\operatorname{ADC}(\%)$} & \multicolumn{6}{|c|}{ Plant protein ingredients } & \multicolumn{5}{|c|}{ Animal protein ingredients } & \multirow{3}{*}{ SEM $^{\mathrm{a}}$} \\
\hline & Fava & Camilina & Soybean & Pea & Sunflower & Wheat & Defatted & Fish & Krill & Poultry & Squid & \\
\hline & $\begin{array}{l}\text { bean } \\
\text { meal }\end{array}$ & meal & meal & meal & meal & gluten & $\begin{array}{l}\text { krill } \\
\text { meal }\end{array}$ & meal & meal & meal & meal & \\
\hline \multicolumn{13}{|l|}{$E A A^{b}$} \\
\hline Arginine & $41.0^{\mathrm{g}}$ & $37.7^{\mathrm{h}}$ & $68.8^{\mathrm{f}}$ & $79.2^{\mathrm{d}}$ & $72.3^{\mathrm{e}}$ & $84.1^{\mathrm{c}}$ & $89.1^{\mathrm{a}}$ & $90.0^{\mathrm{a}}$ & $86.6^{\mathrm{b}}$ & $82.7^{\mathrm{c}}$ & $90.3^{\mathrm{a}}$ & 0.8 \\
\hline Histidine & $47.4^{\mathrm{e}}$ & $42.9^{\mathrm{ef}}$ & $85.4^{\mathrm{b}}$ & $77.0^{\mathrm{cd}}$ & $81.0^{\mathrm{bc}}$ & $77.6^{\mathrm{cd}}$ & $90.2^{\mathrm{a}}$ & $90.3^{\mathrm{a}}$ & $81.8^{\mathrm{bc}}$ & $91.5^{\mathrm{a}}$ & $92.1^{\mathrm{a}}$ & 1.5 \\
\hline Isoleucine & $53.6^{\mathrm{e}}$ & $39.7^{\mathrm{f}}$ & $68.8^{d}$ & $64.4^{\mathrm{d}}$ & $69.3^{\mathrm{d}}$ & $78.0^{\mathrm{c}}$ & $89.0^{\mathrm{a}}$ & $91.0^{\mathrm{a}}$ & $80.7^{b c}$ & $85.8^{\mathrm{ab}}$ & $85.5^{\mathrm{ab}}$ & 1.5 \\
\hline Leucine & $51.5^{\mathrm{f}}$ & $46.7^{\mathrm{g}}$ & $72.6^{d}$ & $63.4^{\mathrm{e}}$ & $70.6^{d}$ & $79.4^{\mathrm{c}}$ & $85.4 \mathrm{~b}$ & $87.6^{\mathrm{ab}}$ & $77.0^{\mathrm{c}}$ & $91.4^{\mathrm{a}}$ & $90.9^{\mathrm{a}}$ & 1.2 \\
\hline Lysine & $64.2^{\mathrm{d}}$ & $41.2^{\mathrm{e}}$ & $79.0^{\mathrm{bc}}$ & $69.9^{\mathrm{cd}}$ & $78.7^{\mathrm{bc}}$ & $70.1^{\mathrm{cd}}$ & $91.6^{\mathrm{ab}}$ & $93.7^{\mathrm{a}}$ & $78.1^{b c}$ & $83.8^{\mathrm{ab}}$ & $90.7^{\mathrm{ab}}$ & 2.5 \\
\hline Methionine & $61.4^{\mathrm{f}}$ & $65.5^{\mathrm{e}}$ & $47.4^{\mathrm{g}}$ & $66.5^{\mathrm{e}}$ & $63.3^{\mathrm{ef}}$ & $93.5^{\mathrm{ab}}$ & $86.6^{\mathrm{c}}$ & $92.0^{\mathrm{b}}$ & $72.3^{\mathrm{d}}$ & $95.4^{\mathrm{a}}$ & $88.2 \mathrm{c}$ & 0.9 \\
\hline Phenylalanine & $57.1^{\mathrm{f}}$ & $57.1^{\mathrm{f}}$ & $65.1^{\mathrm{e}}$ & $78.1^{\mathrm{d}}$ & $81.0^{\mathrm{d}}$ & $85.2^{\mathrm{c}}$ & $87.0^{\mathrm{bc}}$ & $93.6^{\mathrm{a}}$ & $80.7^{\mathrm{d}}$ & $89.3^{b}$ & $80.4^{\mathrm{d}}$ & 1.0 \\
\hline Threonine & $45.8^{\mathrm{d}}$ & $50.2^{\mathrm{d}}$ & $62.6^{\mathrm{c}}$ & $64.1^{\mathrm{c}}$ & $67.8^{\mathrm{c}}$ & $79.7^{b}$ & $69.2^{\mathrm{c}}$ & $90.0^{\mathrm{a}}$ & $84.1^{\mathrm{ab}}$ & $90.8^{\mathrm{a}}$ & $93.1^{\mathrm{a}}$ & 2.3 \\
\hline Valine & $53.1^{\mathrm{c}}$ & $55.2^{\mathrm{c}}$ & $69.7^{\mathrm{bc}}$ & $63.2^{\mathrm{bc}}$ & $70.7^{\mathrm{bc}}$ & $76.3^{\mathrm{ab}}$ & $86.5^{\mathrm{a}}$ & $92.0^{\mathrm{a}}$ & $88.0^{\mathrm{a}}$ & $90.4^{\mathrm{a}}$ & $90.8^{\mathrm{a}}$ & 4.3 \\
\hline
\end{tabular}




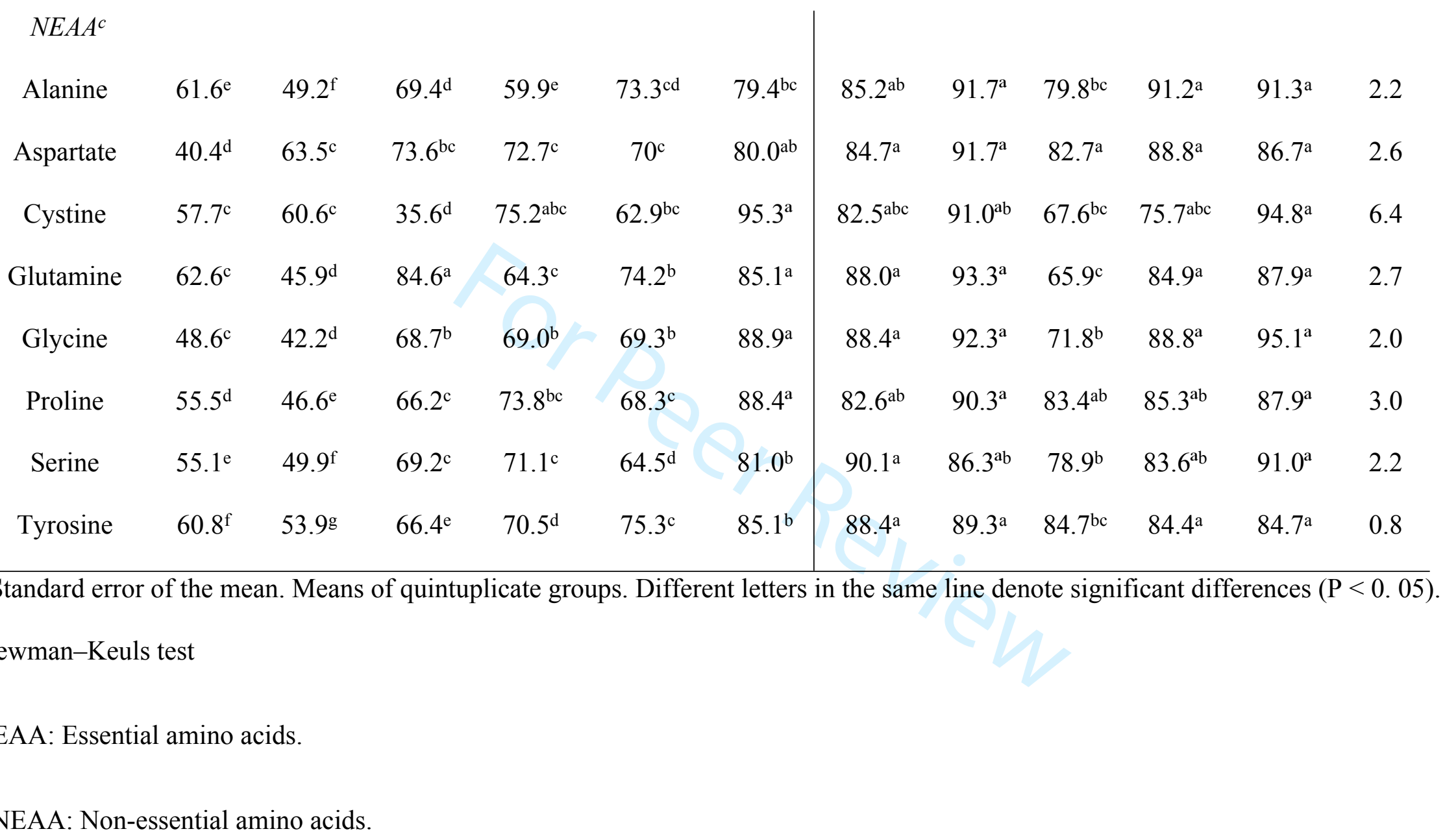


FIGURE 1. Amino acid ratios (\%) for essential digestible amino acids in vegetable ingredients (A) and in animal ingredients (B). EAA of whole body of Seriola dumerili were used to estimate this index as $\mathrm{AA}_{\text {reference }}$ (expressed in $\mathrm{g} / 100 \mathrm{~g}$ of protein): Arg (7.14), His (2.65), Iso (4.76), Leu (7.50), Lys (8.14), Met (2.37), Phe (4.32), Thr (3.85), Val (5.60). 


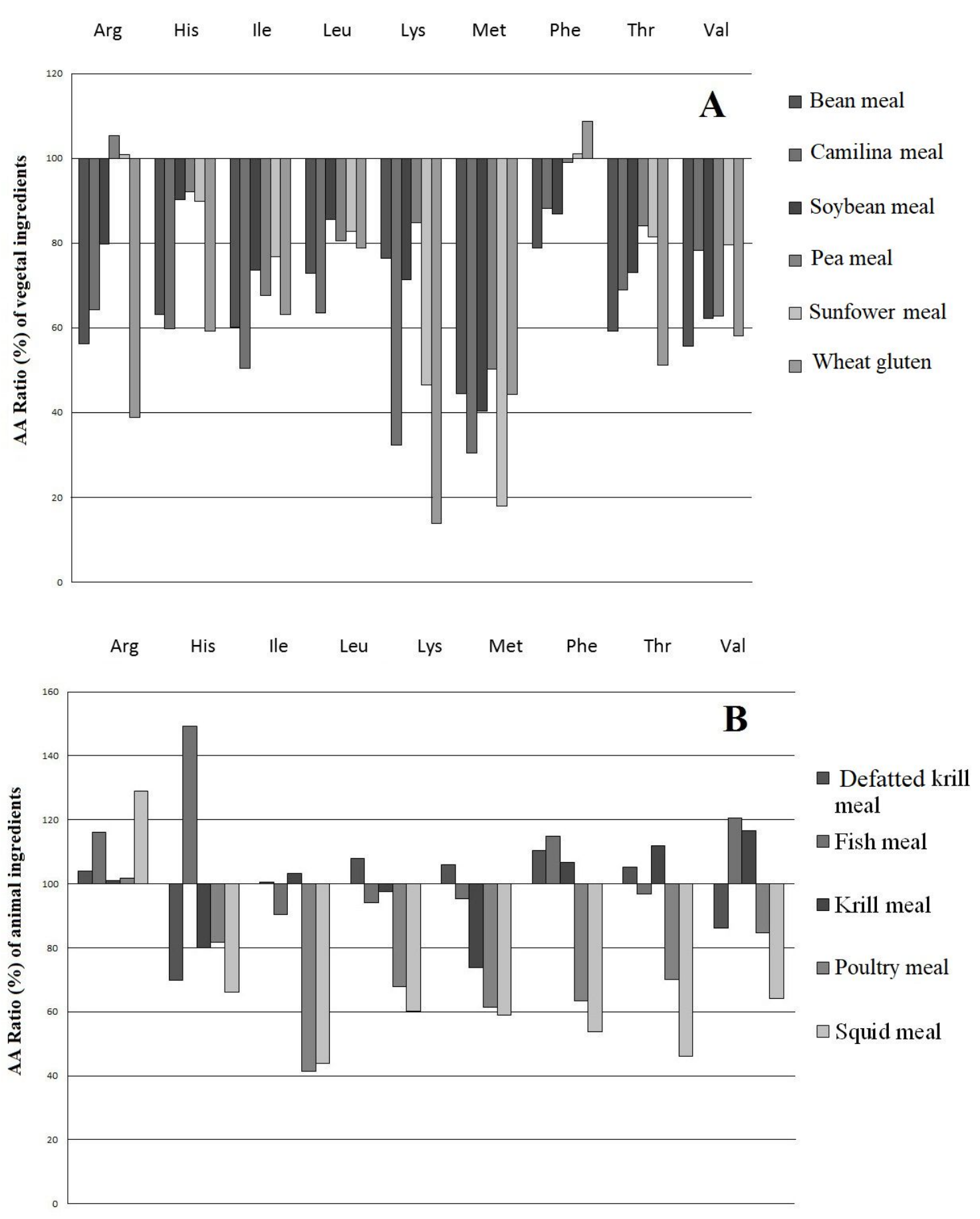


FIGURE 2. Oser's index (OI), Chemical Score (CS) and limiting amino acid in test ingredients for digestible amino acids. 


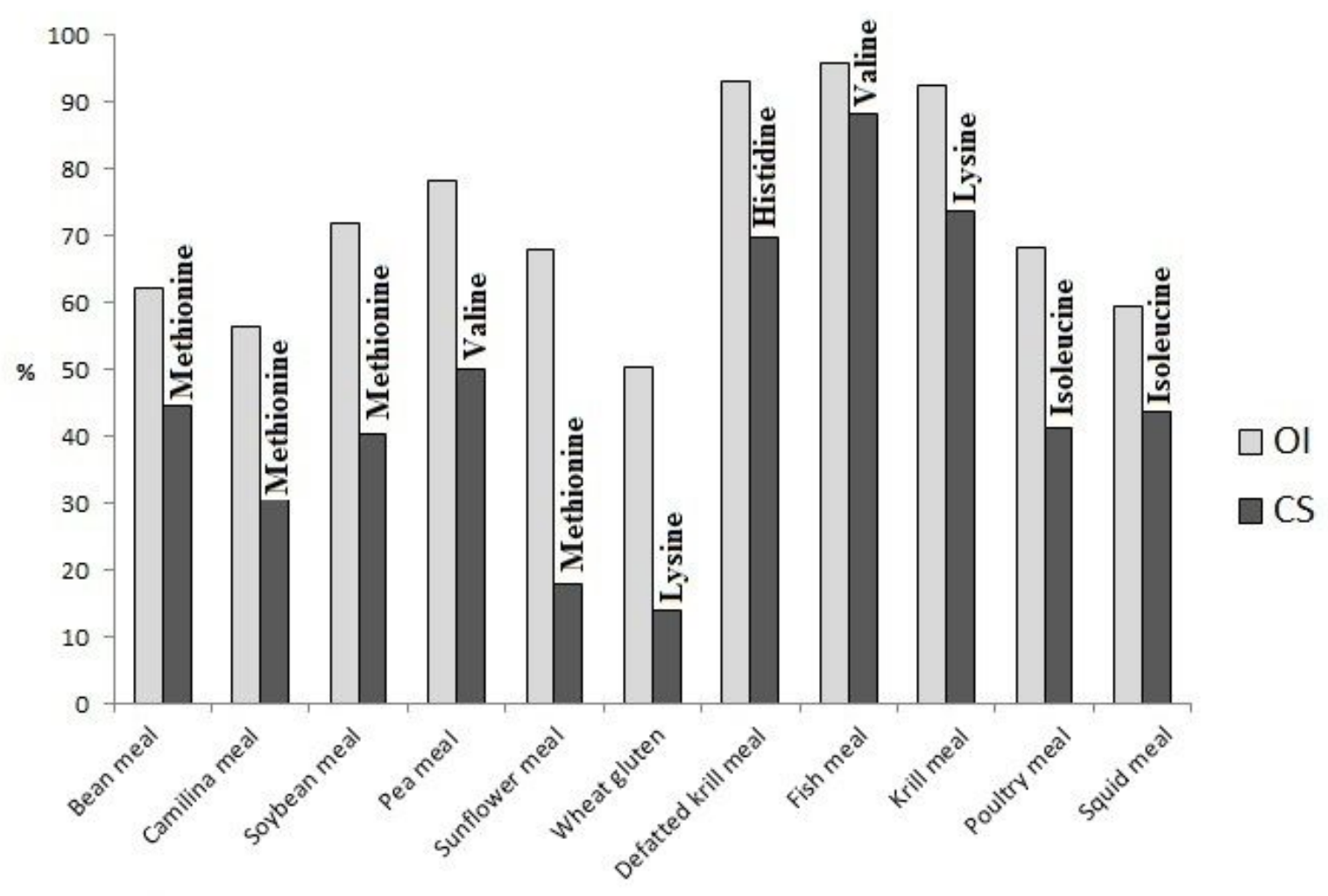

31

35

36

37

38 
1

2

3

4

5

6

7

Apparent Digestibility and Protein Quality Evaluation of Selected Feed Ingredients in Seriola dumerili.

10 Ana Tomás-Vidal, Raquel Monge-Ortiz, Miguel Jover-Cerdá, Silvia Martínez-Llorens.

11 Research Group of Aquaculture and Biodiversity. Institute of Animal Science and

12 Technology. Universitat Politècnica de València. Camino de Vera, 14. 46071-Valencia, 13 Spain.

19 Corresponding author: Raquel Monge-Ortiz, Universitat Politècnica València.

20 Camino de Vera, 14. 46071-Valencia (Spain). Tel.: 34-96-3879752; Fax: 34-96-

213877439. E-mail: silmarll@dca.upv.es. 
Abstract

The apparent digestibility coefficients (ADC) of dry matter, crude protein, crude lipid, and amino acids in fish, krill, squid, meat, defatted krill, soybean,

wheat gluten, wheat, camilina, pea, sunflower and fava bean meals were

determined for juvenile Seriola dumerili. The results showed that the ADC of dry matter for yellowtail ranged from 57.7 to $87.2 \%$ for animal ingredients, and from 42.2 to 82.2\% for plant ingredients. ADC of protein exceeding 90\% were observed in fishmeal, while camilina meal and fava bean meal presented the lowest values. Pea meal presented the lowest lipid ADC (83.5\%). The availabilities were generally higher in animal ingredients than those in vegetal ones. Except camilina and fava bean meal, the other ingredients appear to be favorable for Seriola dumerili diets, especially the ones from animal sources. The lower case chemical score values (minimum value from AARs) were obtained in some vegetal ingredients (14 to $18 \%$ ), while the highest ones, appeared in marine ingredients (69 to $88 \%$ ). According to Oser's Index, the most balanced protein for yellowtail with regard to essential amino acids was in krill, defatted krill, and fishmeal (92 to $96 \%$ ). So, animal sources are suitable as protein ingredients, but they could be enhanced through some essential amino acid supplementation. 
44

45

46

47

48

49

50

51

52

53

54

55

56

57

58

59

60

61

62

63

64

65

66

67

68

In the last two decades the European aquaculture sector has shown an increasing interest and demand in fast-growing species (Mazzola et al. 2000) such as

Mediterranean yellowtail ( $\underline{\text { Seriola }} \underline{\text { dumerili)}}$, as they can improve the competitiveness of aquaculture companies.

The most expensive component in feed formulation in aquaculture is protein.

This is especially important considering that Seriola species require high protein dietary levels (450550 $\left.\mathrm{g} \mathrm{kg}^{-1}\right)$ for maximum growth (Masumoto et al. 1998; Jover et al. 1999; Tomás et al. 2008), and the dietary substitution of proteins by other nutrients—such as lipids or carbohydrates - is not the best solution for the formulation of feeds for $\underline{\mathrm{S}}$. dumerili (Jover et al. 1999). In this sense, fishmeal is an ideal protein source for carnivorous fish, because it contains a balanced amino acid composition, high content of phosphorous and minerals and high digestibility coefficients. However, its high cost motivated its reduction in aqua feeds, while maintaining the same protein levels from alternative protein sources.

Currently, in order to avoid the dependence on fishmeal, aquaculture diets should contain high amounts of alternative proteins that are more widely available and that have lower and more stable market prices than this marine resource. Alternative proteins include a large range of plant or animal proteins with competitive prices (Martínez-Llorens, Vidal, \& Cerdá, 2012). Despite these economic advantages, previous results on Mediterranean yellowtail show that alternative proteins cannot totally replace fishmeal when they are used as the sole ingredient. When soybean is included to replace over $30 \%$ of the fishmeal, it resulted in poor growth and showed low nutrient efficiency (Tomás et al. 2005). Total fishmeal substitution presents some limitations in fish diets, such as the anti-nutrients that are particularly contained in vegetable proteins (Krogdahl et al. 2010), causing a protease enzyme activity decrease and, therefore, low protein 
digestibility (Monge-Ortiz et al. 2016). Another issue related to the use of alternative protein sources is the inadequate profile of amino acids (Cerezo et al. 2012), which results in poor fish growth and protein deficiencies. This forces the use of supplemental diets with synthetic amino acids, which increases the feed price. The best growth and nitrogen retention results when combination of protein sources are used, that include a combination of aminoacids in order to complement one source with limiting ones, that is the case of Sparus aurata (Kissil \& Lupatsch, 2004; Sánchez-Lozano et al., 2009), and evidence suggests that for other species too, like $\underline{\text { Salmo }} \underline{\text { salar }}$ (Espe, 2006) or Seriola dumerili (Monge-Ortiz et al, 2017). For this reason, the combination of animal proteins (such as defatted krill and poultry meal) with plant proteins in fish diets could be beneficial to palliate the deficiencies in amino acids of some protein sources, thus reducing the anti-nutrient compounds and avoiding supplementation with synthetic aminoacids (AAs), lack of palatability (Oliva-Teles 2012) and 'green liver' (Takagi et al. 2005). The adequate proportion to simulate the ideal amino acid profile in diets for the Mediterranean yellowtail will require studies on the digestibility and the protein quality of these ingredients.

Therefore, the evaluation of feed ingredients is crucial to nutritional research and feed development for aquaculture species (Glencross et al. 2007). The alternative protein sources and their inclusion levels need to be optimized in fish diets to make aquaculture production more efficient and cost-effective. Digestibility trials are essential to shed light on the potential of these ingredients for fish before their inclusion in diet formulations. 
94 digestibility coefficient (ADC) values of feed ingredients are normally the result of

95 differences in species, changes in the harvest/catch season of the raw materials and conditions under which they were processed. For that reason, studies on various marine fish species have been conducted (Lupatsch et al. 1997; Tibbets et al.2004; Booth et al. different ingredients.

Taking into account the relevance of digestibility estimation for diet formulation, the aim of this present study was to compare the apparent nutrient digestibility and protein quality of 12 different commercially available ingredients for Seriola dumerili.

\section{Materials and Methods}

\section{$\underline{\text { Ingredients and Experimental Diets }}$}

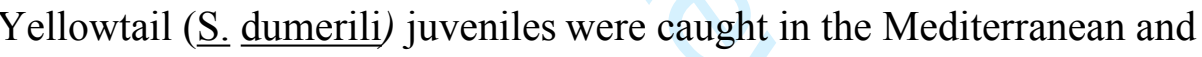
transferred to the facilities of the Polytechnic University of Valencia, Spain.

Feed ingredients were tested for apparent protein digestibility, availability of digestible amino acids and protein quality in fishmeal, krill meal, squid meal, poultry meal (international feed number 5-03798), defatted krill meal (a product obtained by removing the fat with ethanol), soybean ( $\underline{\text { Glycine }} \underline{\max })$, wheat gluten (Triticum spp), camilina (Camelina sativa) (product given to our facilities by local farmers), pea (Pisum

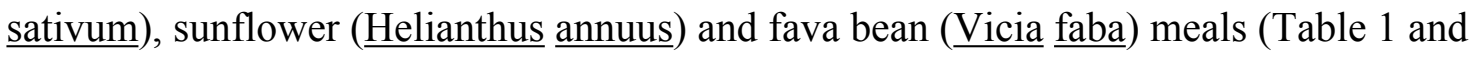
3). Test diets were prepared by mixing a basal diet with one of the test ingredients (Table 2) in a ratio of 7 to 3, as described by Cho and Slinger (1979). 
116 The different ingredients of the diets were weighed individually and mixed to form

117 homogeneous dough, and were prepared by cooking-extrusion processing with a a semi-

118 industrial twin-screw extruder (CLEXTRAL BC-45, St. Etienne, France). The

119 conditions under which they were processed are as follows: a screw speed of $100 \mathrm{rpm}$, a

120 temperature of $110 \mathrm{C}$, and a pressure of 40-50 atm. The experimental diets were assayed

121 in quintuplicate. The fish were handfed once a day $(8.00 \mathrm{~h})$, and fecal collection

122 occurred $8 \mathrm{~h}$ later (16:00h). The pellet size used was $3 \mathrm{~mm}$ during the experiment,

123 increasing to $4 \mathrm{~mm}$ in the final part of the experiment. The pellets were slowly

124 distributed to give all fish time to eat. The uneaten diet was collected when fish had

125 finished feeding.

126

127

128

129

130

131

132

133

134

135

136

137

138

139

\section{Digestibility Assay}

Fifteen yellowtails $(175 \pm 2.8 \mathrm{~g}$ initial mean live weight) were randomly

distributed in five experimental tanks (190 L fiberglass tanks, $88 \mathrm{~cm}$ length, $62 \mathrm{~cm}$

diameter and $188 \mathrm{~cm}$ depth) of a marine semi-closed recirculating system designed on

the basis of the Guelph system (the fecal material being collected in a settling column).

Each tank was loaded with three fish. The velocity of the water flow was adjusted to

minimize settling of the feces in the drainpipe and maximize feces recovery in the settling column.

There was a three-month adaptation period (adaptation to dry diets was a very long process, in which yellowtail were first fed anchovy and, later, a semi-moist diet-a mix of anchovy and fishmeal— - before being fed the control diet). Once the fish had become accustomed to both the tanks and the dietary regime, collection of feces was initiated. 
The fish were fed one meal a day at $10.00 \mathrm{~h}$. The feed was offered only as long

as the fish were actively feeding in order to avoid wastage. One hour after the meal, the

drainpipe and the settling column were brushed out to remove uneaten feed particles and feces from the system to avoid mixing feed particles and feces in the recollection.

Feces were collected next day from the base of the settling column into a plastic container by gravity at $8.00 \mathrm{~h}$. After feces collection, the fish were fed again at $10.00 \mathrm{~h}$, waiting two hours between feces recolection and feeding to avoid stress.

The water temperature was maintained around $20 \mathrm{C}(21.5 \pm 2.4 \mathrm{C})$ during the experimental period by a water conditioning pump (TRANE CAN 490, $123.3 \mathrm{~kW}$ ) installed in the system. All tanks were equipped with aeration and the level of dissolved oxygen was $6.6 \pm 1.3 \mathrm{mg} \mathrm{L}^{-1}$. Water salinity was $31.5 \pm 4.1 \mathrm{~g} / \mathrm{L}, \mathrm{pH} 7.3 \pm 0.4, \mathrm{NO}_{3}{ }^{-}$ $(25-150 \mathrm{mg} / \mathrm{L})$, and $\mathrm{NO}_{2}^{-}(0.05-0.5 \mathrm{mg} / \mathrm{L})$, and the ammonium value was undetectable The photoperiod was maintained at 12-h light and 12-h dark by means of artificial daylight simulation. All these parameters were measured daily from Monday to

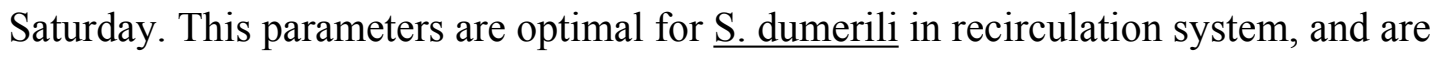
similar that in other Seriola experiments (Jover, 1999; Monge-Ortiz, 2018a, 2018b) Over a six-month period, the fish groups were fed the experimental diets and feces were sampled from each tank. One tank was fed with the control diet over six months to determine the possible variations in digestibility throughout the experimental period. Experimental periods were 14 days long for each diet and each replicate. The last three days of the two-week period fish fasted in order to avoid mixing feces between diets. Feces were removed immediately to determine their amount and have enough for analysis following which fish continued to be fed the same diet for another week. The switching of dietary treatments was as follows: diets with fava bean, camilina, soybean and pea meal were tested from Week 1 to Week 2, from 7 to 8 , from 
16513 to 14 and from 19 to 20 respectively; diets with sunflower, wheat, wheat gluten and 166 defatted krill meal were assayed from $\underline{W}$ week 3 to $\underline{W}$ week 4 , from 9 to 10 , from 15 to 16716 , from 21 to 22 and from 25 to 26, respectively; and diets containing fish, krill, meat 168 and squid meal were tested from Week 5 to 6 , from 11 to 12 , from 17 to 18 , from 23 to 16924 , and from 27 to 28 , respectively of the experimental trial.

170 The fecal material collected was dried to a constant weight in an oven at $60 \mathrm{C}$ for $48 \mathrm{~h}$ 171 prior to analysis and stored in airtight plastic containers until nutrient component and 172 inert marker (acid insoluble ash, AIA) analysis. The AIA content of feeds and feces was 173 determined by the method of Atkinson et al. (1984), to calculate the apparent 174 digestibility coefficient, (ADC).

175 Apparent digestibility coefficients $\left(\mathrm{ADC}_{\text {diet, }} \%\right)$ of each specific nutritional 176 variable (protein (ADCp, \%), lipid (ADCl, \%), and $\mathrm{AA})$ of the diets were calculated 177 using the following formulae:

$$
\mathrm{ADC}_{\text {diet }}=1-\left(\frac{\text { Marker }_{\text {diet }} \times \text { Nutrient }_{\text {faeces }}}{\text { Marker faeces }_{\text {futrient }} \times \text { Niet }_{\text {dut }}}\right)
$$

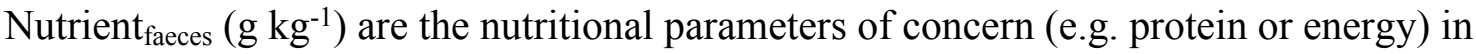
the diet and the feces, respectively. acids for the test ingredients (30\% replacement level) were calculated as follows:

$$
\mathrm{ADCN}_{\text {ing }}=\frac{\left[(a+b) \times \mathrm{ADCN}_{\text {test }}-a \times \mathrm{ADCN}_{\text {ref }}\right]}{b}
$$


In the equation above, " $a$ " is nutrient contribution of reference diet to nutrient

191

\section{$\underline{\text { Chemical Analysis }}$}

Chemical analysis of the dietary ingredients was performed prior to diet formulation (Table 1). Diets and their ingredients were analyzed according to AOAC (1995) procedures: dry matter (105 C to constant weight), ash (incinerated at $550 \mathrm{C}$ to constant weight), crude protein ( $\mathrm{N}$ x 6.25), assessed by the Kjeldahl method after acid digestion (Kjeltec 2300 Auto Analyser, Tecator Höganas, Sweden), and crude lipid, extracted with methyl-ether (Soxtec 1043 extraction unit, Tecator).

Following the aforementioned method by Bosch et al. (2006), the amino acid content of the fish carcasses and the diets were established using a Waters HPLC system (Waters 474, Waters, Milford, MA, USA) with two pumps (Model 515, Waters), an auto-sampler (Model 717, Waters), a fluorescence detector (Model 474, Waters) and a temperature control module. Before hydrolysation, alpha aminobutyric acid was added as an internal standard. The derivatization of amino acids was made by using AQC (6aminoquinolyl-N-hydroxysuccinimidyl carbamate). Methionine and cysteine were determined separately as methionine sulphone and cysteic acid after oxidation with performic acid. Amino acids were separated with a C-17 reverse-phase column Waters Acc. Tag (150 mm x $3.9 \mathrm{~mm})$ and subsequently transformed to Met and Cys. 
Protein Quality

215

The values of the following indices were calculated:

216

- Amino acid ratio $(\mathrm{AAR}, \%)=\left(\mathrm{AA}_{\text {sample }}\right) /\left(\mathrm{AA}_{\text {reference }}\right) * 100$, where $\mathrm{AA}_{\text {sample }}$ and

217

$\mathrm{AA}_{\text {reference }}$ are the digestible amino acid contents in the test sample and whole $\underline{\mathrm{S}}$.

dumerili (Fig. 1), the one taken as reference (average values of 20 samples of fish

219 weighing 100 to $500 \mathrm{~g}$ ).

220

- Chemical score (CS, \%): minimum value from AARs calculated for digestible

essentials amino acids (EAA: Arg, His, Ile, Leu, Lys, Met, Phe, Thr, Val).

222

- Limiting amino acid: the digestible amino acid corresponding to CS in the test sample.

223 - Oser's Index (OI, \%): used as index of nutritional quality and achieved as the

224 geometric mean ratio of digestible amino acids in samples of the ones detected in

225 Seriola dumerili, which were taken as a reference according to the following formula:

OI $(\%)=\left(10^{\left(1 / n^{*}(\log (A A R 1)+\log (\operatorname{AAR} 2) \ldots+\log (A A R n))\right.}\right)$,

in which $\mathrm{AAR}_{1}, \mathrm{AAR}_{2}, \ldots \mathrm{AAR}_{\mathrm{n}}$ are the ratios of digestible essential amino acids, and

" $n$ " is the number of detected digestible essential amino acids. When the ratio lay above 100, this was taken as reference (Oser 1951).

\section{$\underline{\text { Statistical Analysis }}$}

Digestibility coefficients were evaluated using one-way analysis of variance

233 (ANOVA). ACD data were $\log _{10}$ transformed to meet the assumptions of statistical tests

234 (normality, linearity and homosdasticity). The Newman-Keuls test was used to assess

specific differences among diets at a level of $\mathrm{P}<0.05$ (Statgraphics, Statistical Graphics

236

System, Version Plus 5.1, Herndon, Virginia, USA). 


\section{Results}

1. The greatest protein values were observed in animal meals; fishmeal (713.2 $\left.\mathrm{g} \mathrm{kg}^{-1}\right)$

242 wheat gluten (810 g kg-1), squid meal (718.8 g kg-1) and extracted krill meal (723.1 g

$243 \mathrm{~kg}-1)$, while the lowest were found in vegetable meas like pea (215.9 $\mathrm{g} \mathrm{kg}-1)$, fava bean

244 (236.6 g kg-1) and sunflower meal (291.3 g kg-1).

deficiencies in EAA, such as in arginine, threonine, lysine and methionine (Table 3).

Arginine, lysine and leucine were the predominant essential amino acids in animal principal non-essential amino acids present in animal and vegetal meals were aspartate and glutamine.

\section{Digestibility}

The ADCs of dry matter for yellowtail ranged from 71.88 to $89.53 \%$ for animal ingredients, and from 65.89 to $79.98 \%$ for plant products. The higer protein ADCs appeared in fishmeal (91.3\%), wheat gluten (87\%), defatted krill meal (86.7\%), squid meal $(85.2 \%)$ and poultry meal $(85.0 \%)$; mid-range in krill meal $(75.8 \%)$, soybean meal

256 (73.2\%) and sunflower and pea meal (63\%); and low in camilina (48.5\%) and fava bean 257 meal $(54.9 \%)$

Apparent digestibility coefficients of lipids in all the treatments were above $88 \%$, except in the case of pea meal $(83.5 \%)$. 
260

261

262

263

264

265

266

267

268

269

270

271

272

273

274

275

276

277

278

279

280

281

282

283

For the animal ingredientss, the availabilities of amino acids (Table 5) in fish, squid, meat and defatted krill meal were generally higher than those in krill meal.

Among all the plant ingredients, the availabilities of amino acids in wheat gluten were the highest, followed by soybean-, pea- and sunflower meal. Camilina and bean meal presented the lowest AAs ADC.

\section{$\underline{\text { Protein Quality Evaluation }}$}

Defatted krill meal was the most balanced digestible protein ingredient (Figs. 1, 2). It was only deficient in histidine, threonine and valine (AAR: 70 (CS), 86 and 87\%). Fishmeal was slightly deficient in isoleucine, leucine, lysine, phenylalanine and valine (AAR: 90, 94, 95, 97 and $88 \%$, respectively). Krill meal was deficient in histidine, lysine and valine (AAR inferior to $90 \%$ ). Squid and poultry meals presented 60 to $85 \%$ ARRs in all the digestible amino acids, except for arginine, which was the most balanced of them all, while isoleucine was the least balanced (AAR $<50 \%$ ). With respect to the vegetal ingredients, wheat gluten showed the lowest CS (13.98\% for lysine), followed by sunflower, which was found to be deficient in Met (CS: 17.97\%), and camilina meal (poor in methionine, CS 30.8\%). Pea meal proved to be a balanced amino acid ingredient (its CS, Met, was above 50\%).

Oser's Index (OI, Fig. 2) calculated for protein meals was positively related with CS, presenting the lowest values of OI those presented the lowest CS, such in the case of wheat meal and sunflower meal (50.41\% OI, 13.89\% CS and $67.96 \%$ OI, $17.97 \%$ CS respectively). On the contrary, defatted krill and fishmeal (92 to $96 \%$ ) showed the most balanced protein with regard to essential amino acids, whereas all the other ingredients presented lower levels (50-78\%). 
The results obtained in the present study confirmed the very high digestibility of certain animal proteins for carnivorous marine fish (Lupatsch et al., 1997; Tibbets et al. 2006). ADCs of animal proteins were close to those obtained for fishmeal concerning crude protein digestibility, and that fact is probably the result of their very high protein concentrations. Only krill meal ADCp was lower than the other animal protein sources, probably because of the unusually high amount of fat of the krill meal sample used in this study (and consequent low protein level). This was the main difference between the krill meal and the defatted krill meal, which has a lower fat and a higher protein level, making it a higher quality product for yellowtail diets. Tibbetts (2006) obtained similar results with shrimp, with low ADC, due to the high ash content of the shrimp meal.

Protein ADCs of fishmeal assessed in yellowtail are also similar to the ones encountered in turbot ( $\underline{\text { Psetta }} \underline{\text { maxima }})$, seabass (Dicentrarchus labrax $)$, sea bream

( $\underline{\text { Sparus }} \underline{\text { aurata)}})$, Atlantic cod ( $\underline{\text { Gadus }} \underline{\text { morhua })}$, red drum (Sciaenops ocellatus),

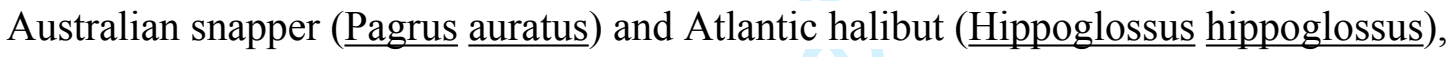
at 91 to 96\% (Gaylord and Gatlin 1996; Lupatsch et al. 1997; Gomes da Silva and Oliva-Teles 1998; Burel et al. 2000; Peach 2005; Tibbetts et al. 2006; Davies et al. 2009; Booth et al. 2010).

Protein ADCs were high for poultry meal (85\%). Animal by-product meals can vary greatly in their proximate composition, depending on several factors (raw material source and freshness, production processes and storage) and, due to its very nature, the values reported for protein ADCs are also highly variable in studies on fish. In many fish species, poultry meal has received positive results in diets (ADCp 85.5\% in sea bass, 79 to $80 \%$ in sea bream, $78.4 \%$ in turbot, and $80 \%$ in Atlantic cod), and is

Davies et al. 2009). 
Atlantic cod (Tibbetts et al. 2006) was nearly $100 \%$, very different indeed to the krill

ADCp in yellowtail (76\%), but that krill meal was obtained through finely grinding

whole krill that had previously been freeze-dried (Euphausia superba) and, therefore, the proximate composition was fairly different from the one found in commercially produced krill meals like the one used in the present work. Those discrepancies are explained by the differences in product quality, as in the case of the defatted krill meal (full-fat krill meal) with a higher protein level.

There are numerous studies on digestibility of soybean meal on various fish species. The protein ADC, however, varied a great deal (76 to 98\%). Yellowtail is within this range, although on the lower side, i.e. among the species that present a lower soybean protein digestibility. Other authors observed a decrease in protein digestibility (Robaina et al. 1995; Refstie et al. 1999), mainly attributed to the presence of phytate.

323 for other marine fish (100\%), like seabass (Robaina et al. 1999) and Atlantic cod

324 (Tibbetts et al. 2006). The high palatability and digestibility, together with the absence of anti-nutritional factors, make wheat gluten meal, supplemented with some amino acids (lysine, methionine and arginine), a suitable fishmeal replacement candidate in 327 yellowtail diets.

Pea meal had a middle ADCp. This ingredient appears to have some potential for its use in marine fish diets (Sánchez-Lozano et al. 2009, 2011); nonetheless it should be pre-extruded in order to boost the digestibility of non-protein ingredients. well digested by Seriola dumerili. There were only slight differences in this parameter 
333 between soybean meal and most of the raw materials. Several studies have concluded 334 that dietary soybean meal decreases the lipid digestibility in salmonids (Romarheim et 335 al. 2008). This fact must be attributed to the bile acid level, which is reduced by dietary 336 soybean meal (Romarheim et al. 2006; Yamamoto et al. 2007). Regarding the availability of AAs, it should be noted that the digestibility of each AA within a feed ingredient is variable. This variability, nonetheless, increases in those ingredients with a lower protein ADC (AAs ADC of camilina or fava bean meals were between 38 and 66\%). In general, apparent digestibility coefficients of AAs reflect the apparent CP digestibility coefficients of some test ingredients. In some of them, however, there are differences, like in wheat gluten, in which apparent digestibility coefficients of AAs were lower than ADCp. On the contrary, krill meal, pea meal or poultry meal presented higher AA ADCs. Thus, amino acid availabilities cannot always be estimated from the ingredient ADCp. Fishmeal and defatted krill meal are the most balanced digestible amino acid ingredients and have one advantage: they benefit from having a higher protein content and CS than krill. However, the defatted krill meal also has one shortcoming: the need for histidine supplementation. Regarding other animal sources, squid meal was the most balanced amino acid in arginine and poultry meal protein quality was similar to camilina and soybean meal.

Despite the high protein digestibility observed in present work for some protein meals, the biological value of the protein should also be taken into account before diet formulation to include them in fish diets. For example, wheat gluten digestibility resulted very high, however it shows a low OI and the lowest CS (in this case Lysine) and therefore it cannot replace the fishmeal in high dietary levels for Mediterranean yellowtail feeding. 
It has been observed in studies performed with sea bream (Lupatsch et al. 1997)

358

359

360

361

362

363

364

365

366

367

368

369

370

371

372

373

374

375

376

377

378

379

that, when using ACDp values obtained for individual ingredients to calculate the

ACDp for compounds diets, both values were very similar, and consequently, protein

digestibility can be considered to be additive. Therefore, ACDp results obtained in this

present experiment, along with the protein quality assessments, should be taken into

account for formulating diets for Mediterranean yellowtail. This is a useful tool to

simulate the ideal protein in diets because, by combining different ingredients, the

inclusion of synthetic amino acids could be avoided or diminished, which would reduce

the cost of fish diets and improve protein digestion.

In conclusion, animal sources are evidently suitable as protein ingredients in yellowtail diets, although the protein quality indices present in them could be enhanced through some essential amino acid supplementation. None of the vegetal meals assayed could offer a good nutritional balance on their own and, therefore, they would either need to be supplemented or need to be used together with other raw materials.

\section{Acknowledgments}

Project financed by the "Ministerio de Ciencia e Innovación" (reference AGL201130547-C03). We would also thank IEO (Instituto Español de Oceanografía), Centro

Oceanográfico de Murcia (España) and Dr. Fernando de la Gándara for providing us the fish used in the present study. 
381

382

AOAC. 1995. Official Methods of Analysis of the Association of Official Analytical Chemists 16th Edition (16th ed.)AOAC Inc., Arlington, Virginia, USA

Atkinson J.L., Hilton J.W. and S.J. Slinger. 1984. Evaluation of acid insoluble ash as

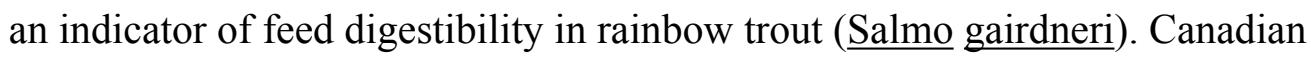
Journal of Fisheries and Aquatic Sciences, 41:1384-1386

Booth M.A., Allan G.L. and A.J. Anderson. 2005. Investigation of the nutritional requirements of Australian snapper Pagrus auratus (Bloch \& Schneider, 1801): apparent digestibility of protein and energy sources. Aquaculture Research, $36: 378-390$

Booth M.A., Allan G.L. and I. Pirozzi. 2010. Estimation of digestible protein and energy requirements of yellowtail kingfish Seriola lalandi using a factorial approach. Aquaculture, 307:247-259.

Bosch L., Alegria A. and R. Farré. 2006. Application of the 6-aminoquinolyl-Nhydroxysuccinimidyl carbamate (AQC), reagent to the RP-HPLC determination of amino acids in infant foods. Journal of chromatography. B, Analytical technologies in the biomedical and life sciences, 831:176-178.

Bureau, D.P., Harris, A.M. and Cho, C.Y. 1999. Apparent digestibility of rendered animal protein ingredients for rainbow trout (․ㅡcorhynchus $\underline{\text { mykiss)}}$. Aquaculture, 180: 345-358.

Burel C., Boujard T., Tulli F. and S.J. Kaushik. 2000. Digestibility of extruded peas, extruded lupin and rapeseed meal in rainbow trout ( $\underline{\text { Oncorhynchus mykiss }}$ ) and turbot (Psetta maxima). Aquaculture, 188:285-298 
403

404

405

406

407

408

409

410

411

412

413

414

415

416

417

418

419

420

421

422

423

424

425

Cerezo Valverde J., Martínez-Llorens S., Tomás Vidal A., Jover M., Rodríguez C., Estefanell J., Gairín J.I., Domingues P.M., Rodríguez C.J. and B. García. 2012. Amino acids composition and protein quality evaluation of marine species and meals for feed formulations in cephalopods. Aquaculture International, $21: 413-433$

Cho C. Y. and S.J. Slinger. 1979. Apparent digestibility measurement in feedstuffs for rainbow trout, Pages 239-247 in J. Halver, K. Tiews (Eds.), Proc. World Symp. on Finfish Nutrition and Fishfeed Technology, vol. 2 Heenemann, Berlin.

Davies J., Gouveia A., Laporte J., Woodgate S. and S. Nates. 2009. Nutrient digestibility profile of premium (category III grade) animal protein by-products for temperate marine fish species (European sea bass, gilthead sea bream and turbot). Aquaculture Research, 40:1759-1769.

Forster I. 1999. A note on the method of calculating digestibility coefficients of nutrients provided by single ingredients to feeds of aquatic animals. Aquaculture Nutrition, 5:143-145.

Gaylord T.G. and D.M. Gatlin. 1996. Determination of digestibility coefficients of various feedstuffs for red drum ( $\underline{\text { Sciaenops ocellatus) }}$. Aquaculture, 139:303-314.

Glencross B.D., Booth M. and G.L. Allan. 2007. A feed is only as good as its ingredients - a review of ingredient evaluation strategies for aquaculture feeds. Aquaculture Nutrition, 13:17-34.

Gomes da Silva J. and A. Oliva-Teles. 1998. Apparent digestibility coefficients of feedstuffs in seabass (Dicentrarchus labrax) juveniles. Aquatic Living Resources, 11:187-191. 
426 Jover M., García-Gómez A., Tomás A., De la Gándara F. and L. Pérez. 1999.

427 Growth of the Mediterranean yellowtail (Seriola dumerili) fed extruded diets

428 containing different levels of protein and lipid. Aquaculture, 179:25-33.

429 Krogdahl Å., Penn M., Thorsen J., Refstie S. and A.M. Bakke. 2010. Important

430 antinutrients in plant feedstuffs for aquaculture: an update on recent findings

431 regarding responses in salmonids. Aquaculture Research, 41:333-344.

432

433

434

435

436

437

438

439

440

441

442

443

444

445

446

447

448
Lupatsch I., Kissil G., Sklan, D. and E. Pfeffer. 1997. Apparent digestibility coefficients of feed ingredients and their predictability in compound diets for gilthead seabream, Sparus aurata L. Aquaculture Nutrition, 3:81-89.

Martínez-Llorens, S., Vidal, A. T. and M.J. Cerdá. 2012. A new tool for determining the optimum fish meal and vegetable meals in diets for maximizing the economic profitability of gilthead sea bream (Sparus aurata, L.) feeding. Aquaculture Research, 43:1697-1709.

Masumoto T., Itoh Y., Ruchimat T., Hosokawa H. and S. Shimeno. 1998. Dietary amino acids budget for juvenile yellowtail (Seriola quinqueradiata). Bulletin of Marine Science and Fisheries, 18:33-37.

Mazzola, A., Favaloro, E. and G.L. Sarà. 2000. Cultivation of the Mediterranean amberjack, Seriola dumerili (Risso, 1810), in submerged cages in the Western Mediterranean Sea. Aquaculture, 181:257-268.

\section{Monge-Ortiz R., Martínez-Llorens S., Márquez L., Moyano F.J., Jover-Cerdá M.} and A. Tomás-Vidal. 2016. Potential use of high levels of vegetal proteins in diets for market-sized gilthead sea bream (ㅁarus $\underline{\text { aurata) }}$. Archives of Animal Nutrition, 70 http://dx.doi.org/10.1080/1745039X.2016.1141743 
449

450

451

452

453

454

455

456

457

458

459

460

461

462

463

464

465

466

467

468

469

470

471

\section{Monge-Ortiz R., Tomás-Vidal A., Rodriguez-Barreto D., Martínez-Llorens S.,} Pérez J.A., Jover-Cerdá M., Lorenzo A. 2018. Replacement of fish oil with

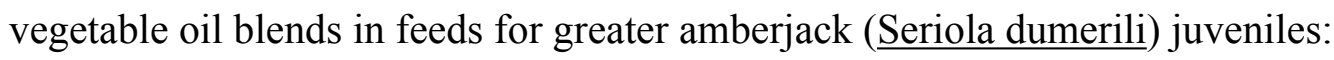
Effect on growth performance, feed efficiency, tissue fatty acid composition and flesh nutritional value. Aquculture Nutrition. 24:605-615.

\section{Monge-Ortiz R., Tomás-Vidal A., Gallardo-Álvarez F.J., Estruch G., Godoy-} Olmos S., Jover-Cerdá M., Martínez-Llorens S. 2018. Partial and total replacement of fishmeal by a blend of animal and plant proteins in diets for

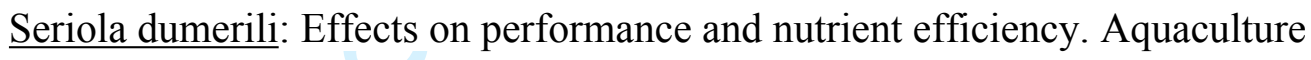
Nutrition, 24:1163-1174.

Oliva-Teles A. 2012. Nutrition and health of aquaculture fish. Journal of Fish Diseases, $35: 83-108$.

Oser B.L. 1951. Methods for integrating essential amino acid content in the nutritional evaluation of protein. Journal of the American Dietetic Association, 27:396-402.

Peach R.W. 2005. Protein and energy utilization by juvenile Atlantic halibut ( Scotia Agricultural College, Truro, Nova Scotia.

Refstie S., Svihus B., Shearer K.D. and Storebakken, T. 1999. Nutrient digestibility in Atlantic salmon and broiler chickens related to viscosity and non-starch polysaccharide content in different soybean products. Animal Feed Science and Technology, 79:331-345.

\section{Robaina L., Izquierdo M.S., Moyano F.J., Socorro J., Vergara J.M., Montero D.} and H. Fernández-Palacios. 1995. Soybean and lupin meals as protein sources in 
472 diets for gilthead sea bream ( 473 implications. Aquaculture, 130:219-233.

474 Robaina L., Corraze G., Aguirre P., Blanc D., Melcion J.P. and S. Kaushik. 1999. Digestibility, postprandial ammonia excretion and selected plasma metabolites in European sea bass (Dicentrarchus labrax) fed pelleted or extruded diets with or

\section{Romarheim O.H., Skrede A., Penn M., Mydland L.T., Krogdahl A. and T.}

Storebakken. 2008. Lipid digestibility, bile drainage and development of morphological intestinal changes in rainbow trout (Oncorhynchus mykiss) fed diets containing defatted soybean meal. Aquaculture, 274:329-338

\section{Sánchez-Lozano N.B., Martínez-Llorens S., Tomás-Vidal A. and M. Jover Cerdá.} 2009. Effect of high-level fishmeal replacement by pea and rice concentrate protein on growth, nutrient utilization and fillet quality in gilthead sea bream (Sparus aurata, L.). Aquaculture, 298:83-89.

\section{Sánchez-Lozano N., Martínez-Llorens S., Tomás-Vidal A. and M. Jover-Cerdá. 2011. Amino acid retention of gilthead sea bream (Sparus aurata, L.) fed with pea protein concentrate. Aquaculture Nutrition, 17:e604-e614.}


493 Tibbetts S.M., Lall S.P. and J.E. Milley. 2004. Apparent digestibility of common feed 494

495 ingredients by juvenile haddock, Melanogrammus aeglefinus. L. Aquaculture Research, 35:643-651.

496

Tibbetts S.M., Milley J.E. and S.P. Lall. 2006. Apparent protein and energy

497 digestibility of common and alternative feed ingredients by Atlantic cod, Gadus

498 morhua (Linnaeus, 1758). Aquaculture, 261:1314-1327.

499

500

501

502

503

504

505

506

507

508

509

510

511

512

Tomás A., De la Gándara F., García-Gómez A., Pérez, L. and M. Jover. 2005. Utilization of soybean meal as an alternative protein source in the Mediterranean yellowtail, Seriola dumerili. Aquaculture Nutrition, 11:333-340.

Tomás A., De la Gándara F., García-Gómez A. and M.J. Cerdá. 2008. Effect of the protein/energy ratio on the growth of Mediterranean yellowtail (Seriola dumerili). Aquaculture Research, 39:1141-1148.

Takagi S., Murata H., Goto T., Ichiki T., Munasinghe D.M., Endo M., Matsumoto T., Sakurai A., Hatate H., Yoshida T., Sakai T., Yamashita H., Ukawa M. and T. Kuramoto. 2005. The green liver syndrome is caused by taurine deficiency in Yellowtail, Seriola quinqueradiata fed diets without fishmeal. Aquaculture Science, 53:279-290.

\section{Yamamoto T., Suzuki N., Furuita H., Sugita T., Tanaka N. and T. Goto. 2007.} Supplemental effect of bile salts to soybean meal-based diet on growth and feed utilization of rainbow trout Oncorhynchus mykiss. Fisheries Science, 73:123-131 
513 TABLE 1. Proximate composition of ingredients used in the digestibility trial (expressed as $\mathrm{g} \mathrm{kg}^{-1}$ of dry matter basis, dm).

\begin{tabular}{|c|c|c|c|c|c|}
\hline Ingredients $^{\mathrm{a}}\left(g \mathrm{~kg}^{-1}\right)$ & Dry matter & Crude Protein & Crude lipid & Ash & $\mathrm{N}$-free extract \\
\hline \multicolumn{6}{|l|}{ Plant protein ingredients } \\
\hline Fava bean meal & 890 & 237 & 12 & 33 & 718 \\
\hline Camilina meal & 918 & 391 & 45 & 61 & 503 \\
\hline Soybean meal & 882 & 499 & 22 & 71 & 408 \\
\hline Pea meal & 866 & 216 & 10 & 39 & 736 \\
\hline Sunflower meal & 896 & 291 & 15 & 67 & 627 \\
\hline Wheat meal & 890 & 116 & 15 & 18 & 851 \\
\hline Wheat gluten & 933 & 810 & 9 & 9 & 173 \\
\hline \multicolumn{6}{|c|}{ Animal protein ingredients } \\
\hline Defatted krill meal & 878 & 723 & 24 & 102 & 151 \\
\hline Fish meal & 903 & 713 & 93 & 168 & 26 \\
\hline Krill meal & 888 & 561 & 225 & 104 & 111 \\
\hline Poultry meal & 970 & 531 & 153 & 269 & 47 \\
\hline
\end{tabular}



Squid meal
928
719
30
110
142

514 a Wheat (Triticum spp), Sunflower (eㅏianthus annuus L.), pea (Pisum sativum L.), fava bean (Vicia faba L.) and soybean meal ( $\underline{\text { Glycine max }}$ L.

515 Merr.) were provided by DESCO, Museros, Valencia (Spain); Defatted krill meal was provided by LUDAN RENEWABLE ENERGY, Valencia

516 (Spain); Wheat gluten and Camilina (Camelina sativa, L. Crantz) were provided by DADELOS AGRÍCOLA, Valencia (Spain); Poultry meal was

517 provided by VALGRA S.A., Beniparrell, Valencia (Spain); Krill meal was provided by AKER SEAFOODS ANTATARCTIC, S. A. Lysaker

518 (Norway); Squid meal was provided by MAX NOLLERT, Utrecht (Netherlands). 
520 TABLE 2. Formulation and apparent digestibility coefficients of the experimental diets.






\begin{tabular}{|c|c|c|c|c|c|c|c|c|c|c|c|c|}
\hline Poultry meal & & & & & & & & & & & 300 & \\
\hline Squid meal & & & & & & & & & & & & 300 \\
\hline Fish oil & 75 & 52.5 & 52.5 & 52.5 & 52.5 & 52.5 & 52.5 & 52.5 & 52.5 & 52.5 & 52.5 & 52.5 \\
\hline $\begin{array}{l}\text { Multivitamin and } \\
\text { mineral mix }\end{array}$ & 20 & 14 & 14 & 14 & 14 & 14 & 14 & 14 & 14 & 14 & 14 & 14 \\
\hline Crude Protein (\% w.w.) & 46.2 & 37.4 & 41.3 & 40.3 & 35.8 & 37.4 & 55.2 & 56.0 & 53.0 & 45.4 & 51.3 & 49.5 \\
\hline Crude Lipids (\% w.w.) & 12.2 & 9.0 & 10.1 & 8.8 & 8.7 & 9.0 & 9.0 & 13.0 & 13.9 & 13.8 & 14.8 & 10.9 \\
\hline AIA ( $g k^{-1}$ dry matter) & 2.2 & 2.2 & 3.1 & 3.1 & 2.8 & 1.6 & 1.8 & 2.0 & 3.5 & 3.4 & 3.6 & 3.0 \\
\hline Dry matter ADC (\%) & 84.8 & 72.1 & 76.4 & 75.8 & 76.5 & 78.9 & 84.1 & 78.6 & 83.9 & 76.6 & 80.2 & 81.0 \\
\hline Protein ADC (\%) & 96.9 & 85.8 & 83.6 & 90.4 & 88.5 & 90.2 & 94.5 & 93.5 & 97.5 & 90.0 & 93.8 & 96.1 \\
\hline Lipid ADC (\%) & 98.5 & 96.2 & 97.5 & 94.9 & 96.1 & 97.2 & 98.2 & 96.6 & 98.2 & 96.8 & 98.1 & 96.7 \\
\hline
\end{tabular}

521 
TABLE 3. Amino acid composition of ingredients (expressed as $\mathrm{g} \mathrm{kg}^{-1}$ of dry matter basis, dm).

\begin{tabular}{|c|c|c|c|c|c|c|c|c|c|c|c|c|}
\hline & \multicolumn{7}{|c|}{ Plant protein ingredients } & \multicolumn{5}{|c|}{ Animal protein ingredients } \\
\hline & \multirow[b]{2}{*}{ Fava bean } & \multirow[b]{2}{*}{ Camilina } & \multirow[b]{2}{*}{ soybean } & \multirow[b]{2}{*}{ Pea } & \multirow[b]{2}{*}{ Sunflower } & \multirow[b]{2}{*}{ Wheat } & \multirow[b]{2}{*}{ Wheat } & \multicolumn{5}{|c|}{ Poultr } \\
\hline & & & & & & & & Defatted & Fish & Krill & $\mathrm{y}$ & Squid \\
\hline & meal & meal & meal & meal & meal & meal & gluten & krill meal & meal & meal & meal & meal \\
\hline \multicolumn{13}{|l|}{$E A A^{a}\left(g k g^{-1}\right)$} \\
\hline Arginine & 17.7 & 36.7 & 32.3 & 15.2 & 27.7 & 4.6 & 25.7 & 53.9 & 60.5 & 42.2 & 37.2 & 63.3 \\
\hline Histidine & 6.6 & 10.3 & 12.5 & 5.0 & 8.4 & 2.4 & 14.5 & 13.0 & 29.1 & 12.8 & 10.8 & 12.0 \\
\hline Isoleucine & 9.2 & 15.1 & 20.5 & 8.5 & 14.7 & 3.6 & 30.1 & 34.2 & 32.2 & 32.5 & 10.1 & 15.2 \\
\hline Leucine & 18.1 & 28.6 & 37.2 & 15.4 & 24.7 & 6.7 & 57.9 & 57.5 & 55.5 & 47.4 & 26.2 & 32.6 \\
\hline Lysine & 17.0 & 17.9 & 30.5 & 16.6 & 13.7 & 3.2 & 12.1 & 58.0 & 56.9 & 38.4 & 25.6 & 33.8 \\
\hline Methionine & 2.8 & 3.2 & 8.1 & 3.1 & 1.8 & 6.3 & 8.8 & 17.5 & 20.2 & 16.8 & 7.5 & 8.4 \\
\hline Phenylalanine & 9.8 & 19.1 & 23.0 & 9.6 & 16.2 & 4.5 & 43.1 & 33.2 & 30.8 & 30.3 & 15.8 & 15.5 \\
\hline Threonine & 8.3 & 16.9 & 17.5 & 7.5 & 13.0 & 3.2 & 19.5 & 31.1 & 34.2 & 27.8 & 16.8 & 18.0 \\
\hline
\end{tabular}




\begin{tabular}{|c|c|c|c|c|c|c|c|c|c|c|c|c|}
\hline Valine & 10.1 & 22.4 & 20.3 & 9.2 & 18.0 & 4.7 & 32.6 & \multirow[t]{2}{*}{35.6} & \multirow[t]{2}{*}{37.6} & \multirow[t]{2}{*}{31.7} & \multirow[t]{2}{*}{17.6} & \multirow[t]{2}{*}{23.6} \\
\hline$N E A A^{b}(g \mathrm{~kg}-$ & & & & & & & & & & & & \\
\hline Alanine & 9.8 & 18.8 & 19.0 & 8.3 & 14.8 & 3.5 & 20.0 & 41.4 & 45.8 & 33.1 & 36.8 & 52.6 \\
\hline Aspartate & 25.9 & 39.4 & 57.7 & 23.6 & 43.6 & 5.4 & 22.3 & 81.0 & 65.1 & 60.3 & 50.8 & 46.0 \\
\hline Cystine & 2.1 & 4.5 & 4.1 & 2.0 & 2.9 & 7.1 & 11.2 & 3.5 & 6.6 & 3.8 & 7.3 & 35.8 \\
\hline Glutamine & 41.3 & 76.8 & 94.1 & 36.7 & 74.9 & 28.9 & 319.8 & 110.5 & 92.2 & 75.2 & 69.9 & 102.6 \\
\hline Glycine & 10.2 & 23.3 & 18.6 & 8.4 & 20.2 & 4.7 & 24.5 & 30.6 & 48.3 & 27.8 & 75.4 & 106.9 \\
\hline Proline & 8.9 & 22.7 & 21.7 & 7.4 & 16.0 & 9.4 & 108.2 & 23.8 & 29.7 & 23.0 & 42.7 & 53.6 \\
\hline Serine & 12.1 & 17.3 & 24.2 & 9.6 & 15.4 & 4.9 & 36.7 & 29.1 & 29.9 & 24.8 & 22.8 & 22.9 \\
\hline Tyrosine & 4.2 & 9.7 & 12.4 & 3.5 & 6.7 & 1.3 & 22.9 & 29.3 & 23.0 & 27.3 & 11.2 & 11.8 \\
\hline $\begin{array}{c}\text { Ratio } \\
\text { EAA/NEAA }\end{array}$ & 0.87 & 0.80 & 0.80 & 0.91 & 0.71 & 0.60 & 0.43 & 0.96 & 1.05 & 1.02 & 0.53 & 0.51 \\
\hline
\end{tabular}

523 aEAA: Essential amino acids.

524 bNEAA: Non-essential amino acids. 
TABLE 4. Apparent digestibility coefficients (ADCs) for dry matter, crude protein and crude lipid in test ingredient consumed by yellowtail.

\begin{tabular}{|c|c|c|c|c|c|c|c|c|c|c|c|c|}
\hline \multirow[b]{2}{*}{$\mathrm{ADC}(\%)$} & \multicolumn{6}{|c|}{ Plant protein ingredients } & \multicolumn{5}{|c|}{ Animal protein ingredients } & \multirow{4}{*}{$\mathrm{SEM}^{\mathrm{a}}$} \\
\hline & Fava & Camilina & Soybean & Pea & Sunflowe & Wheat & Defatted & Fish & Krill & Poultr & Squid & \\
\hline & bean & meal & meal & meal & r meal & gluten & krill meal & meal & meal & $\mathrm{y}$ & meal & \\
\hline & meal & & & & & & & & & \multicolumn{2}{|l|}{ meal } & \\
\hline Dry matter & $42.2^{\mathrm{d}}$ & $58.8^{\mathrm{c}}$ & $54.9^{\mathrm{c}}$ & $57.2^{\mathrm{c}}$ & $65.7^{\mathrm{c}}$ & $82.2^{\mathrm{ab}}$ & $68.0^{\mathrm{c}}$ & $87.2^{\mathrm{a}}$ & $57.7^{\mathrm{c}}$ & $70.2^{\mathrm{bc}}$ & $70.1^{\mathrm{bc}}$ & 3.4 \\
\hline Protein & $54.9^{d}$ & $48.5^{\mathrm{e}}$ & $73.2^{\mathrm{c}}$ & $63.0^{\mathrm{d}}$ & $62.9^{d}$ & $87^{\mathrm{b}}$ & $86.7^{\mathrm{b}}$ & $91.3^{\mathrm{a}}$ & $75.8^{c}$ & $85.0^{\mathrm{b}}$ & $85.2^{\mathrm{b}}$ & 1.3 \\
\hline Lipid & $90.2^{\mathrm{ab}}$ & $91.3^{\mathrm{ab}}$ & $91.1^{\mathrm{ab}}$ & $83.5^{\mathrm{c}}$ & $94.0^{\mathrm{a}}$ & $90.8^{\mathrm{ab}}$ & $88.4^{\mathrm{b}}$ & $94.2^{\mathrm{a}}$ & $92.0^{\mathrm{ab}}$ & $93.9^{\mathrm{a}}$ & $88.3^{\mathrm{b}}$ & 1.2 \\
\hline
\end{tabular}

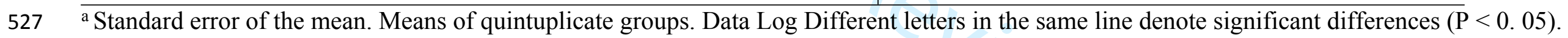

528 Newman-Keuls test. 
TABLE 5. Apparent digestibility coefficients (ADCs) of amino acids in test ingredient consumed by yellowtail.

\begin{tabular}{|c|c|c|c|c|c|c|c|c|c|c|c|c|}
\hline \multirow[b]{2}{*}{$\mathrm{ADC}(\%)$} & \multicolumn{6}{|c|}{ Plant protein ingredients } & \multicolumn{6}{|c|}{ Animal protein ingredients } \\
\hline & Fava & Camilina & Soybean & Pea & Sunflower & Wheat & Defatted & Fish & Krill & Poultry & Squid & $\mathrm{SEM}^{\mathrm{a}}$ \\
\hline & $\begin{array}{l}\text { bean } \\
\text { meal }\end{array}$ & meal & meal & meal & meal & gluten & $\begin{array}{l}\text { krill } \\
\text { meal }\end{array}$ & meal & meal & meal & meal & \\
\hline \multicolumn{13}{|l|}{$E A A^{b}$} \\
\hline Arginine & $41.0^{\mathrm{g}}$ & $37.7^{\mathrm{h}}$ & $68.8^{\mathrm{f}}$ & $79.2^{\mathrm{d}}$ & $72.3^{\mathrm{e}}$ & $84.1^{\mathrm{c}}$ & $89.1^{\mathrm{a}}$ & $90.0^{\mathrm{a}}$ & $86.6^{\mathrm{b}}$ & $82.7^{\mathrm{c}}$ & $90.3^{\mathrm{a}}$ & 0.8 \\
\hline Histidine & $47.4^{\mathrm{e}}$ & $42.9^{\mathrm{ef}}$ & $85.4^{\mathrm{b}}$ & $77.0^{\mathrm{cd}}$ & $81.0^{\mathrm{bc}}$ & $77.6^{\mathrm{cd}}$ & $90.2^{\mathrm{a}}$ & $90.3^{\mathrm{a}}$ & $81.8^{\mathrm{bc}}$ & $91.5^{\mathrm{a}}$ & $92.1^{\mathrm{a}}$ & 1.5 \\
\hline Isoleucine & $53.6^{\mathrm{e}}$ & $39.7^{\mathrm{f}}$ & $68.8^{\mathrm{d}}$ & $64.4^{\mathrm{d}}$ & $69.3^{d}$ & $78.0^{\mathrm{c}}$ & $89.0^{\mathrm{a}}$ & $91.0^{\mathrm{a}}$ & $80.7^{\mathrm{bc}}$ & $85.8^{\mathrm{ab}}$ & $85.5^{\mathrm{ab}}$ & 1.5 \\
\hline Leucine & $51.5^{\mathrm{f}}$ & $46.7^{\mathrm{g}}$ & $72.6^{\mathrm{d}}$ & $63.4^{\mathrm{e}}$ & $70.6^{d}$ & $79.4^{\mathrm{c}}$ & $85.4 \mathrm{~b}$ & $87.6^{\mathrm{ab}}$ & $77.0^{\mathrm{c}}$ & $91.4^{\mathrm{a}}$ & $90.9^{\mathrm{a}}$ & 1.2 \\
\hline Lysine & $64.2^{\mathrm{d}}$ & $41.2^{\mathrm{e}}$ & $79.0^{\mathrm{bc}}$ & $69.9^{\mathrm{cd}}$ & $78.7^{b c}$ & $70.1^{\mathrm{cd}}$ & $91.6^{\mathrm{ab}}$ & $93.7^{\mathrm{a}}$ & $78.1^{\mathrm{bc}}$ & $83.8^{\mathrm{ab}}$ & $90.7^{\mathrm{ab}}$ & 2.5 \\
\hline Methionine & $61.4^{\mathrm{f}}$ & $65.5^{\mathrm{e}}$ & $47.4^{\mathrm{g}}$ & $66.5^{\mathrm{e}}$ & $63.3^{\mathrm{ef}}$ & $93.5^{\mathrm{ab}}$ & $86.6^{\mathrm{c}}$ & $92.0^{\mathrm{b}}$ & $72.3^{d}$ & $95.4^{\mathrm{a}}$ & $88.2 \mathrm{c}$ & 0.9 \\
\hline Phenylalanine & $57.1^{\mathrm{f}}$ & $57.1^{\mathrm{f}}$ & $65.1^{\mathrm{e}}$ & $78.1^{\mathrm{d}}$ & $81.0^{\mathrm{d}}$ & $85.2^{\mathrm{c}}$ & $87.0^{\mathrm{bc}}$ & $93.6^{\mathrm{a}}$ & $80.7^{\mathrm{d}}$ & $89.3^{b}$ & $80.4^{\mathrm{d}}$ & 1.0 \\
\hline Threonine & $45.8^{\mathrm{d}}$ & $50.2^{\mathrm{d}}$ & $62.6^{c}$ & $64.1^{c}$ & $67.8^{c}$ & $79.7^{b}$ & $69.2^{\mathrm{c}}$ & $90.0^{\mathrm{a}}$ & $84.1^{\mathrm{ab}}$ & $90.8^{\mathrm{a}}$ & $93.1^{\mathrm{a}}$ & 2.3 \\
\hline
\end{tabular}




\begin{tabular}{|c|c|c|c|c|c|c|c|c|c|c|c|c|c|}
\hline & Valine & $53.1^{\mathrm{c}}$ & $55.2^{\mathrm{c}}$ & $69.7^{\mathrm{bc}}$ & $63.2^{\mathrm{bc}}$ & $70.7^{\mathrm{bc}}$ & $76.3^{\mathrm{ab}}$ & $86.5^{\mathrm{a}}$ & $92.0^{\mathrm{a}}$ & $88.0^{\mathrm{a}}$ & $90.4^{\mathrm{a}}$ & $90.8^{\mathrm{a}}$ & 4.3 \\
\hline \multicolumn{14}{|c|}{$N E A A^{c}$} \\
\hline & Alanine & $61.6^{\mathrm{e}}$ & $49.2^{\mathrm{f}}$ & $69.4^{\mathrm{d}}$ & $59.9^{\mathrm{e}}$ & $73.3^{\mathrm{cd}}$ & $79.4^{\mathrm{bc}}$ & $85.2^{\mathrm{ab}}$ & $91.7^{\mathrm{a}}$ & $79.8^{\mathrm{bc}}$ & $91.2^{\mathrm{a}}$ & $91.3^{\mathrm{a}}$ & 2.2 \\
\hline & Aspartate & $40.4^{\mathrm{d}}$ & $63.5^{\mathrm{c}}$ & $73.6^{\mathrm{bc}}$ & $72.7^{\mathrm{c}}$ & $70^{\mathrm{c}}$ & $80.0^{\mathrm{ab}}$ & $84.7^{\mathrm{a}}$ & $91.7^{\mathrm{a}}$ & $82.7^{\mathrm{a}}$ & $88.8^{\mathrm{a}}$ & $86.7^{\mathrm{a}}$ & 2.6 \\
\hline & Cystine & $57.7^{c}$ & $60.6^{c}$ & $35.6^{\mathrm{d}}$ & $75.2^{\mathrm{abc}}$ & $62.9^{\mathrm{bc}}$ & $95.3^{\mathrm{a}}$ & $82.5^{\mathrm{abc}}$ & $91.0^{\mathrm{ab}}$ & $67.6^{\mathrm{bc}}$ & $75.7^{\mathrm{abc}}$ & $94.8^{\mathrm{a}}$ & 6.4 \\
\hline & Glutamine & $62.6^{\mathrm{c}}$ & $45.9^{d}$ & $84.6^{\mathrm{a}}$ & $64.3^{c}$ & $74.2^{\mathrm{b}}$ & $85.1^{\mathrm{a}}$ & $88.0^{\mathrm{a}}$ & $93.3^{\mathrm{a}}$ & $65.9^{c}$ & $84.9^{\mathrm{a}}$ & $87.9^{\mathrm{a}}$ & 2.7 \\
\hline & Glycine & $48.6^{\mathrm{c}}$ & $42.2^{\mathrm{d}}$ & $68.7^{\mathrm{b}}$ & $69.0^{\mathrm{b}}$ & $69.3^{b}$ & $88.9^{\mathrm{a}}$ & $88.4^{\mathrm{a}}$ & $92.3^{\mathrm{a}}$ & $71.8^{\mathrm{b}}$ & $88.8^{\mathrm{a}}$ & $95.1^{\mathrm{a}}$ & 2.0 \\
\hline & Proline & $55.5^{\mathrm{d}}$ & $46.6^{\mathrm{e}}$ & $66.2^{\mathrm{c}}$ & $73.8^{\mathrm{bc}}$ & $68.3^{\mathrm{c}}$ & $88.4^{\mathrm{a}}$ & $82.6^{\mathrm{ab}}$ & $90.3^{\mathrm{a}}$ & $83.4^{\mathrm{ab}}$ & $85.3^{\mathrm{ab}}$ & $87.9^{\mathrm{a}}$ & 3.0 \\
\hline & Serine & $55.1^{\mathrm{e}}$ & $49.9^{\mathrm{f}}$ & $69.2^{\mathrm{c}}$ & $71.1^{\mathrm{c}}$ & $64.5^{\mathrm{d}}$ & $81.0^{\mathrm{b}}$ & $90.1^{\mathrm{a}}$ & $86.3^{\mathrm{ab}}$ & $78.9^{\mathrm{b}}$ & $83.6^{\mathrm{ab}}$ & $91.0^{\mathrm{a}}$ & 2.2 \\
\hline & Tyrosine & $60.8^{f}$ & $53.9 \mathrm{~g}$ & $66.4^{\mathrm{e}}$ & $70.5^{\mathrm{d}}$ & $75.3^{\mathrm{c}}$ & $85.1^{\mathrm{b}}$ & $88.4^{\mathrm{a}}$ & $89.3^{\mathrm{a}}$ & $84.7^{\mathrm{bc}}$ & $84.4^{\mathrm{a}}$ & $84.7^{\mathrm{a}}$ & 0.8 \\
\hline 531 & \multicolumn{13}{|c|}{${ }^{a}$ Standard error of the mean. Means of quintuplicate groups. Different letters in the same line denote significant differences $(\mathrm{P}<0.05)$} \\
\hline 532 & \multicolumn{13}{|c|}{ Newman-Keuls test } \\
\hline 533 & \multicolumn{13}{|c|}{${ }^{\mathrm{b}}$ EAA: Essential amino acids. } \\
\hline 534 & NE $\triangle \wedge$. & . & 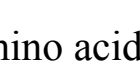 & & & & & & & & & & \\
\hline
\end{tabular}


FIGURE 1. Amino acid ratios (\%) for essential digestible amino acids in vegetable ingredients (A) and in animal ingredients (B). EAA of whole body of Seriola dumerili were used to estimate this index as $\mathrm{AA}_{\text {reference }}$ (expressed in $\mathrm{g} / 100 \mathrm{~g}$ of protein): Arg (7.14), His (2.65), Iso (4.76), Leu (7.50), Lys (8.14), Met (2.37), Phe (4.32), Thr (3.85), Val (5.60). 

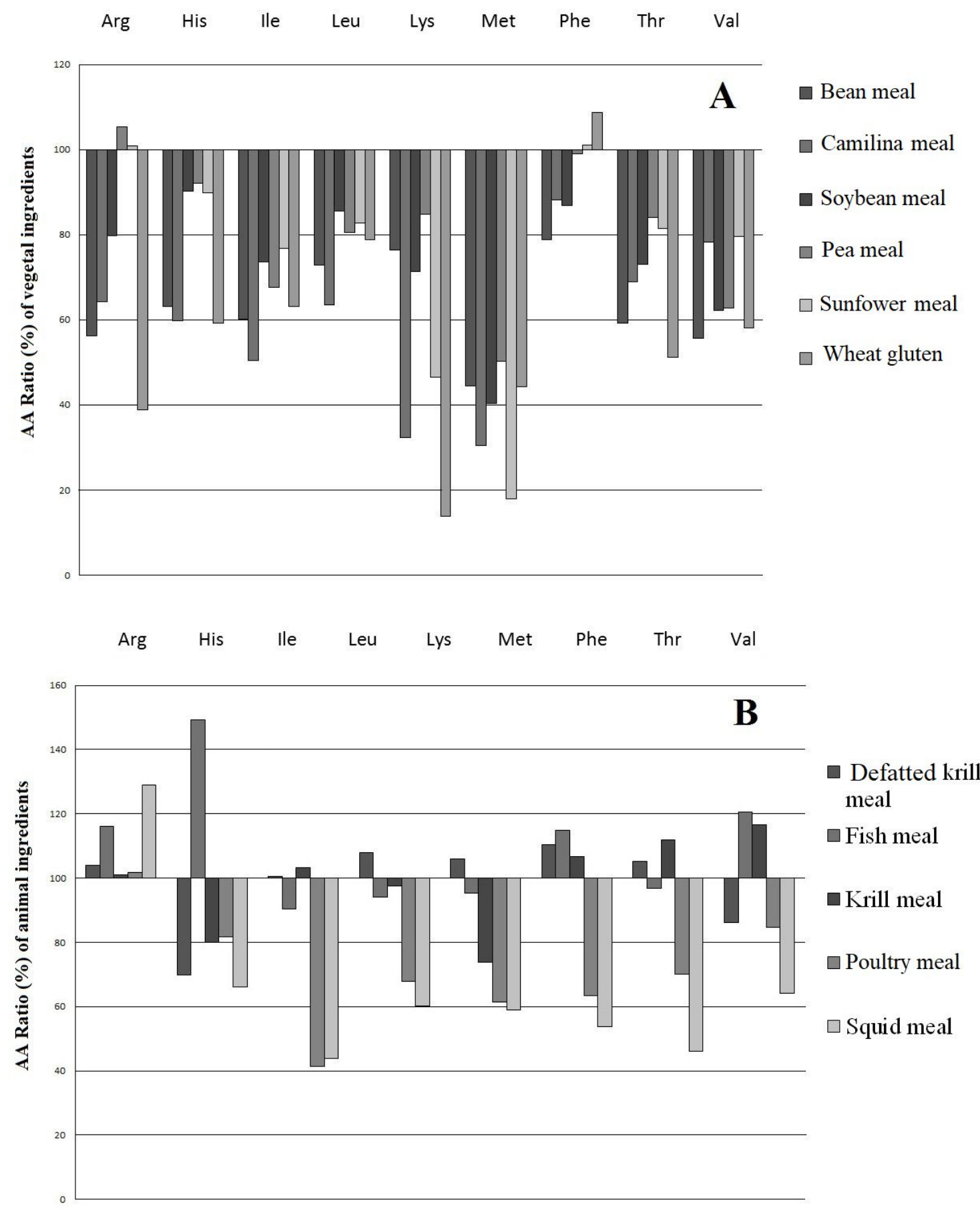
FIGURE 2. Oser's index (OI), Chemical Score (CS) and limiting amino acid in test ingredients for digestible amino acids. 


1
2
3
4
5
6
7
8
9
10
11
12
13
14
15
16
17
18
19
20
21
22
23
24
25
26
27
28
29
30
31
32
33
34
35
36
37
38
39
40
41
42
43
44
45
46
47
48
49
50
51
52
53
54
55
56
57
58
59
60

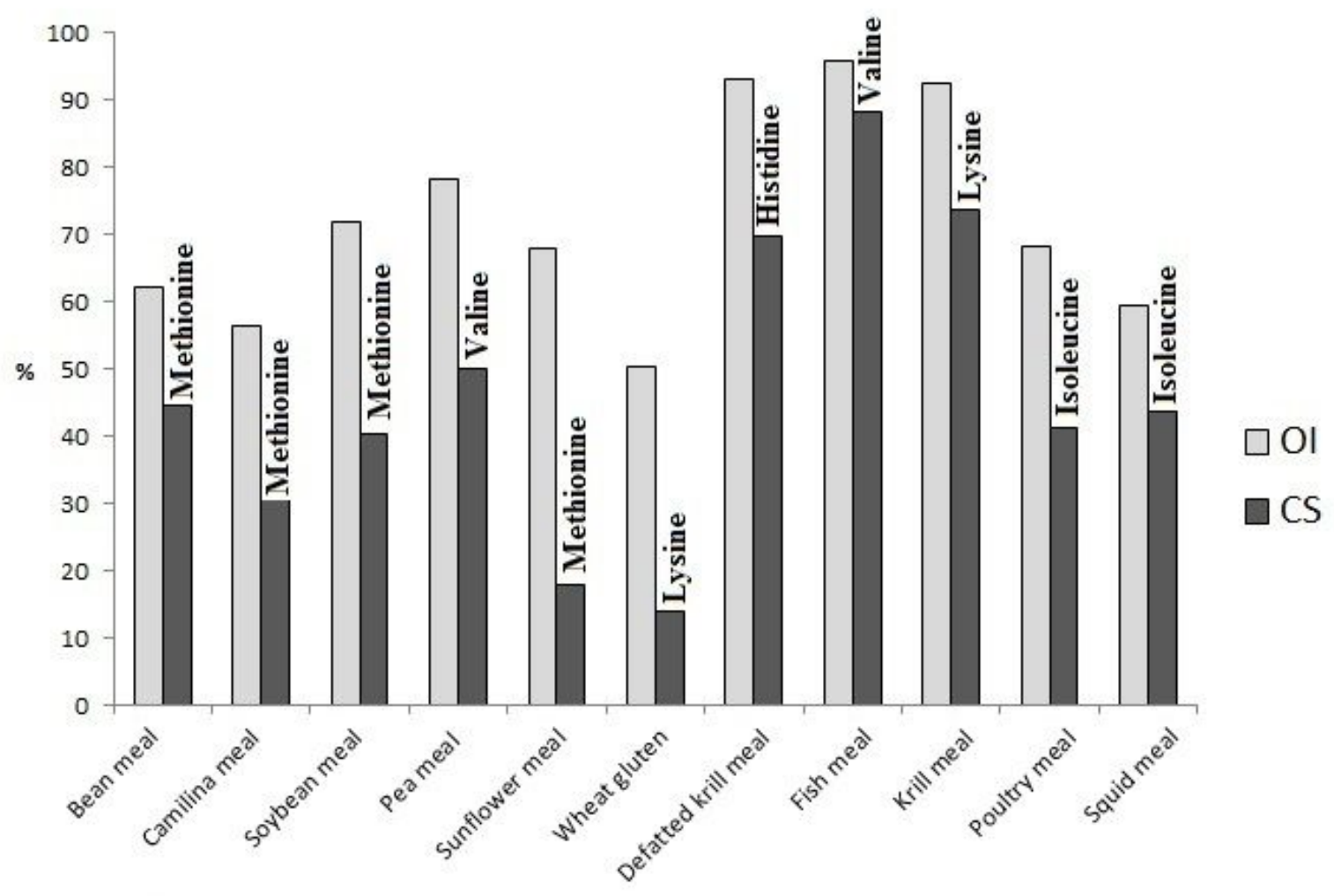

32 